\title{
Adjusting to Trade Policy: Evidence from U.S. Antidumping Duties on Vietnamese Catfish*
}

\author{
Irene Brambilla ${ }^{\dagger}$ \\ Universidad de La Plata \\ and NBER
}

\author{
Guido Porto \\ Universidad de La Plata
}

Alessandro Tarozzi ${ }^{\S}$

Duke University

\section{September 2010}

\begin{abstract}
In 2003, after claims of dumping, the U.S. imposed heavy tariffs on imports of catfish from Vietnam. As a result, Vietnamese exports of catfish to the U.S. market sharply declined. Using a panel data of Vietnamese households, we explore the responses of catfish producers in the Mekong delta between 2002 and 2004. We study adjustments not only in catfish aquaculture but also in other economic activities. We find that, over this period, the rate of income growth was significantly lower among households relatively more involved in catfish farming in 2002. The source of this slower growth is explained by a relative decline in both catfish income and revenues from other miscellaneous farms activities such as poultry and livestock farming. Households did not adjust labor supply, most likely because of off-farm employment limitations. We also document that households more exposed to the shock reduced the share of investment assigned to catfish, while substituting into agriculture.
\end{abstract}

JEL CODES: F13, F14

Key Words: Antidumping, Aquaculture, Trade Policy, Vietnam

${ }^{*}$ We are especially grateful to Quy-Toan Do for his help, encouragement and comments. Matias Horenstein provided outstanding research assistance. Comments and discussions from C. Bown, M. Busso, M. Genoni, M. Haddad, B. Hoekman, A. Khandelwal, N. Minot, T. Prusa, M. Rama, M. Ravallion, C. Turk, D. Van De Walle, and seminar participants at George Washington University, IABD, Michigan State University, University of Michigan, USITC, and the World Bank are greatly appreciated. Financial support from a World Bank Knowledge for Change (KCP) grant is gratefully acknowledged.

${ }^{\dagger}$ Department of Economics, Universidad de La Plata, Argentina. Calle 6 e/ 47 y 48, Piso 5, Oficina 532, La Plata, Argentina. email: irene.brambilla@econo.unlp.edu.ar

${ }^{\ddagger}$ Department of Economics, Universidad de La Plata, Argentina. Calle 6 e/ 47 y 48, Piso 5, Oficina 521, La Plata, Argentina. email: guido.porto@depeco.econo.unlp.edu.ar

${ }^{\S}$ Duke University. Dept. of Economics, PO Box 90097, Durham, NC, 27708. email: taroz@econ.duke.edu 


\section{Introduction}

The number of antidumping (AD) cases filed with the World Trade Organization tripled between the early 1980s and the late 1990s (Prusa, 2005). The number of AD users has increased as well, and today countries such as India, Argentina, Mexico, Brazil, South Africa and New Zealand have become users as frequent as the United States, the European Union, Canada and Australia. Forty-six countries adopted AD laws between 1990 and 2001 (Zanardi, 2004). Overall, AD activity is increasing and likely to continue increasing in the near future.

There is a large empirical literature on antidumping (see Blonigen and Prusa, 2003). Debaere (2005) and Prusa (1997) study changes in international equilibrium prices, while Blonigen and Haynes (2002) and Blonigen and Park (2004) explore the pass-through to domestic prices. Bown and Crowley (2007), Staiger and Wolak (1994), and Prusa (1997) document changes in trade volumes, trade deflection and trade depression. In turn, Gallaway, Blonigen and Flynn (1999) quantify aggregate welfare costs and Blonigen and Bown (2003) focus on issues of retaliation and further trade liberalization. In this paper, we are interested in exploring the impact of $\mathrm{AD}$ measures (adopted by developed countries) on income-generating activities of rural households in developing countries. In light of the increasingly heavy use of AD, our estimates of these microeconomic impacts should become valuable additions to the set of current evaluations of $\mathrm{AD}$ policies.

The concrete case at the core of our paper is the antidumping duties imposed by the United States on imports of catfish fillets from Vietnam in 2003. After the U.S. lifted the embargo on Vietnam in 1994, Vietnamese catfish burst into the U.S. market, which by 
2002 became the main export destination and accounted for 50 percent of total production. Catfish farming quickly became an important source of income for households in the Mekong delta in Southern Vietnam. However, such form of aquaculture is also an important industry in the Southern United States (mainly in Mississippi, Arkansas, Alabama, and Louisiana). The Association of Catfish Farmers of America (CFA), faced with an increasing competition from cheaper Vietnamese catfish, and deeming such competition unfair, initiated a successful campaign to halt catfish imports. First, the CFA pursued a labeling campaign whereby Vietnamese products were forced to be sold as 'tra' and 'basa,' a different product from the American 'channel' catfish. Later, the CFA launched dumping allegations. In January 2003, the U.S. Department of Commerce (DoC) ruled in favor of the dumping claim of the CFA and established tariffs ranging from 37 to 64 percent on imports of frozen catfish (that is, tra and basa) from Vietnam. In July 2003, the U.S. International Trade Commission (USITC) ratified the DoC ruling. As a result, Vietnamese exports of catfish to the U.S. plummeted to the point of being almost completely shut down.

Our objective in this paper is to explore patterns of household adjustment to this AD shock among Mekong farmers in Vietnam. In world markets where export barriers abound (sometimes intertwined with export preferences), one of the main concerns with the trade policies of developed countries is how such policies affect welfare in trade partners in the developing world. For this reason, we focus here on adjustments in the process of generation of household income. We first establish the overall response of household income to the U.S. AD policy among catfish farmers in the Mekong. We also document how income adjustment takes place in the presence of potential spillovers from the activities directly affected by the 
trade shocks (catfish in our case) to other household occupations (such as agriculture). To do this, we investigate the impact on various sources of household income, and we inspect household adjustments in input decisions such as labor supply and investment in catfish and non-catfish activities.

Our identification strategy is based on the comparison of household outcomes before and after the U.S. AD intervention across catfish farmers with different levels of exposure to the shock. As our measure of exposure, we use fishing income shares as proxies for catfish income shares and we exploit the regional variation in exposure generated by the fact that catfish thrives only in a few provinces of the Mekong delta. This regional heterogeneity in catfish exposure also allows us to produce several successful validation results lend support to our identification strategy.

The Vietnamese catfish case is ideal for ex-post analysis. First, the 2003 U.S. decision is a trade shock which is arguably exogenous with respect to decisions taken by Vietnamese households. Second, the General Statistical Office in Vietnam collected two household surveys, the Vietnam Household Living Standard Surveys of 2002 and 2004, that span the period right before and after the U.S. trade policy. The combination of an exogenous policy change with ex-ante and ex-post data provides a unique opportunity to explore household responses to trade shocks. There are only few other studies that analyze ex-post the impact of trade policies on household income and production decisions. Edmonds and Pavcnik (2005) find that the increase in the price of rice that followed market integration in Vietnam led to declines in child labor, especially in households that were large net producers of rice. Topalova (2005) studies the impact on poverty and inequality of trade liberalization in India 
in the early 1990s and finds that rural areas with industries more exposed to liberalization experienced less poverty reduction. For the same Indian liberalization process, Edmonds, Pavcnik, and Topalova (2009) find that areas with more concentration of protected industries saw a lower increase in schooling and a lower decline in child labor. Finally, McCaig (2008) studies the impact of the 2001 U.S.-Vietnam Bilateral Trade Agreement on poverty and finds that areas more affected by U.S. tariff cuts experienced larger declines in poverty. We find that income growth was significantly lower for farmers more dependent on catfish income. Our preferred estimates show that, relative to households with only marginal involvement in catfish production, the average catfish farmer faced a 15.8 percent lower growth in total income (standard error 5.7 percent). The impact was instead 8.7 percent (s.e. 3.3) for households with low exposure and 23.6 percent (s.e. 8.0) for high-exposure farmers.

Consistently with these results, the growth in catfish income was significantly lower among farmers more exposed to the AD shock. We also find evidence of spillovers of the AD shock to non-catfish activities. While growth in wage and agricultural income were not affected, growth in income from miscellaneous farm activities (such as poultry, livestock and farm services) was negatively associated with exposure, and such association was both statistically and economically significant. In addition, growth in investment in catfish farming was significantly lower for households more exposed to the shock. The same was true for investments in miscellaneous farm activities, although in this case our estimates are large but not statistically significant. On the other hand, Mekong farmers shifted resources into agricultural investments, and we find that households more exposed to the shock saw relatively larger rates of growth along this dimension. 
The rest of the paper is organized as follows. In section 2, we illustrate the timeline of the U.S. antidumping measures on Vietnamese catfish. In section 3, we describe the production of catfish in Vietnam and we characterize the catfish farmers of the Mekong delta. In section 4, we introduce our estimation strategy and we document the changes in household income. In section 5, we explore the pattern of household adjustment to the trade shock. Finally, section 6 concludes.

\section{The US Antidumping Ruling on Vietnamese Catfish}

Catfish is a fresh-water fish that thrives in large, flat rivers. In the U.S., catfish is raised in man-made ponds mainly in the states of Mississippi, Arkansas, Alabama, and Louisiana. ${ }^{1}$ Farmers buy fingerlings (young fish) and feed them for approximately ten weeks. Processing plants purchase farm-raised catfish and market mostly fresh or frozen fillets in about equal parts. The catfish industry is by far the largest farm-raised fishing sector in the U.S. In 1999, it accounted for 80 and 64 percent of aquaculture production in volume and value, generating 440 million dollars of revenue (USITC, 2001). There are over 1,000 catfish farms and 25 processing plants in the Southeast. Most of the catfish produced in the U.S. is a high quality variety known as channel catfish, which, before the introduction of Vietnamese catfish, accounted for almost all domestic consumption (with total imports of less than 1 percent).

The Hau and Tien rivers in the Mekong region of South Vietnam also provide a good

\footnotetext{
${ }^{1}$ There is also some production of catfish in California, Florida, Georgia, Kentucky, Missouri, North Carolina, and Texas.
} 
habitat for catfish. The Vietnamese varieties, known as basa and tra, are raised by small farmers in cages that are placed in the river itself and later processed in industrialized plants. While tra is of lower quality than basa in terms of flavor and texture, it is faster, easier, and less costly to raise and has become the most popular of the two species among Mekong producers.

In 1995, soon after the end of the U.S. embargo, Vietnam started exporting frozen fillets of basa and tra to the U.S. market. ${ }^{2}$ As a first effort to popularize the Vietnamese products, more appealing names such as River Cobbler and China Sole were used to market the fish. Later on, retailers labeled basa and tra simply as catfish. They also adopted brand names that suggested a Mississippi-raised origin, such as Cajun Delight Catfish, and used packaging similar to the American channel catfish.

During the late 1990s and early 2000s, catfish exports from Vietnam increased significantly. By 2000-2002, approximately 50 percent of the total Vietnamese production of catfish was being sold to the U.S., and the volume market share in U.S. consumption reached 8.4 percent in 2000 and 19.6 percent in 2002. Vietnamese catfish served mostly food service distributors and chain restaurants - catfish available in supermarkets, on the other hand, is mostly fresh instead of frozen and thus of American origin. The average price of domestic catfish sold by U.S. processors fell by 18 percent between 2000 and 2002, from 2.75 to 2.25 dollars per pound. In turn, during the same time period, Vietnamese production capacity expanded by 100 percent (USITC, 2003).

\footnotetext{
${ }^{2}$ The embargo was lifted by the Clinton administration in February 1994 as a first step before reestablishing diplomatic relations in July 1995 and signing a bilateral trade agreement in December 2001. The 2001 trade agreement granted Vietnam the Most Favored Nation (MFN) status.
} 
The increasing popularity of Vietnamese catfish together with the decrease in domestic prices raised concern within the Association of Catfish Farmers of America (CFA), a trade association of farmers and processors. At first, the CFA blamed the improper labeling of Vietnamese basa and tra as 'catfish' for the lower prices. The allegation was that even though Vietnamese catfish was a different product from American catfish, it was sold under misleading labels that allowed Vietnamese exporters to free ride on the significant commercial campaign and marketing efforts of domestic catfish producers. ${ }^{3}$ Domestic producers launched a "raised in America" campaign to raise awareness among clients and consumers.

The CFA also lobbied in Washington. In October 2001, the U.S. House of Representatives adopted a new bill (H.R. 2964) which established the use of the label 'catfish' only for fishes of the Ictaluridae family (the American catfish), thus forcing Vietnamese exports to be labeled as tra and basa. Subsequently, the 10-digit Harmonized System line corresponding to frozen catfish fillets, 0304.20.60.30, was split into three different lines: 0304.20.60.32 for catfish of the Ictaluridae family; 0304.20.60.33 for catfish of the Pangasiidae family (the Vietnamese catfish); and 0304.20.60.34 for all other siluriformes. The passing of the bill, however, did not lead to a significant recovery in prices. While public awareness increased, most Vietnamese catfish was being sold to American wholesale distributors, not final consumers, and a change in names was not enough to break the commercial networks that had already been established. ${ }^{4}$

\footnotetext{
${ }^{3}$ Strictly, the term "catfish" refers to the order Siluriformes. There are 39 different families of catfish, including the family Ictaluridae and the family Pangasiidae. The American channel catfish (Ictalurus punctatus) is a species in the Ictaluridae family, while the Vietnamese basa (Pangasius bocourti) and tra (Pangasius hypophthalmus) are species in the Pangasiidae family.

${ }^{4}$ For more details on labeling issues and a general description of the evolution of imports of Vietnamese catfish see USITC (2003) and Seafood Business Magazine (2001).
} 
In June 2002, the CFA filed a dumping lawsuit against Vietnam. A few months later, in January 2003, the U.S. DoC ruled in favor of U.S. farmers, arguing that Vietnamese exporters were dumping frozen fish fillets on U.S. markets by margins that varied by exporter and ranged from 37 to 64 percent of the "normal value." ${ }^{5}$ When the exporting country is a "market economy," the DoC determines the normal value of an imported product using either the domestic price or an estimate of the cost of production in the country of origin. Vietnam, however, is considered as a "non-market economy" by the U.S. government, which implies the presumption that domestic prices are distorted. As a consequence, prices and costs in a surrogate country are used instead. In the case of Vietnamese catfish, the surrogate countries used by the DoC were Bangladesh and India. As the last step of the lawsuit, in July 2003, the USITC found that American catfish processors were materially injured by imports from Vietnam, confirming the application of antidumping import tax rates equivalent to the dumping margins of 37 to 64 percent. $^{6}$

Figure 1 plots the time series of U.S. imports of tra and basa from Vietnam (in tons) between January 2002 and July 2004. Data are from the disaggregated monthly import series at the 10-digit level of the Harmonized System. ${ }^{7}$ The graph shows a striking drop in the imported quantities of tra and basa immediately following the DoC announcement in January 2003 (left vertical line). Average monthly imports dropped from nearly 380 monthly tons in 2002, to around 180 in the first semester of 2003, a more than 50 percent decline. After the

\footnotetext{
${ }^{5}$ The DoC established margins of 36.84 percent for Vinh Hoan, 45.55 percent for Afiex, CAFATEX, Da Nang, Mekonimex, QVD, Viet Hai and Vinh Long, 45.81 percent for CATACO, 47.05 percent for Agifish, 53.68 percent for Nam Viet, and 63.88 percent of all other exporters.

${ }^{6}$ The USITC decided to exclude American catfish farmers from the investigation on material injury, and focused only on catfish processors. The argument was that the percentage of unprocessed domestic farmraised catfish that was used as input for frozen fillets, which was about 50 percent, was not high enough.

${ }^{7}$ See the USITC Interactive Tariff and Trade DataWeb, version 2.8.0. at http://dataweb.usitc.gov.
} 
Figure 1

US Imports of tra and basa from Vietnam

Monthly Quantities (tons)

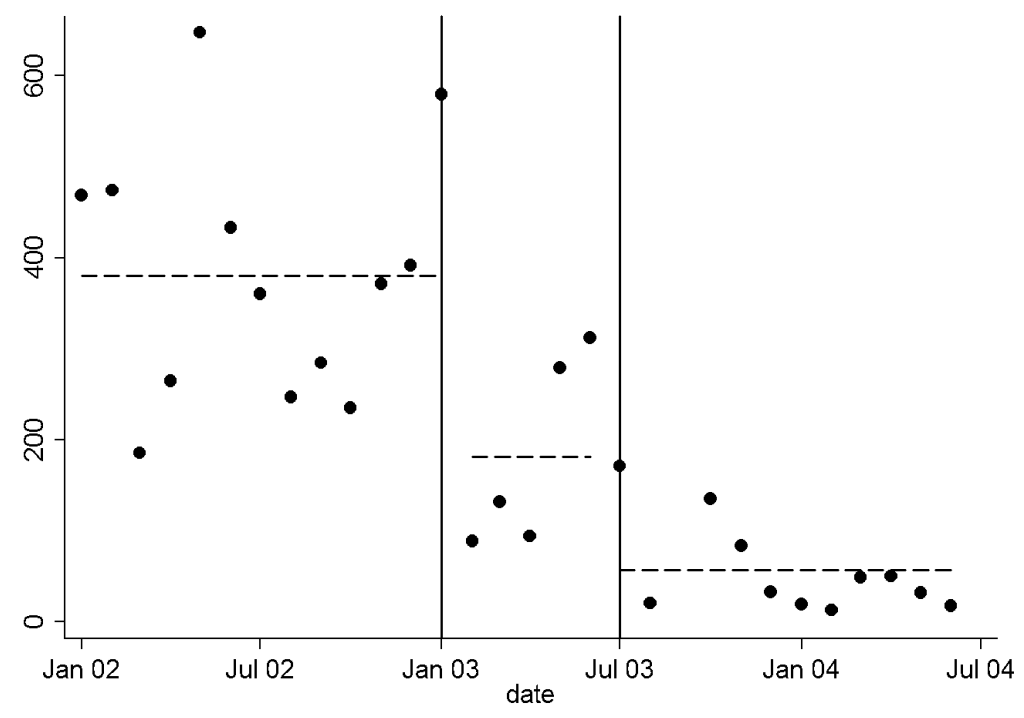

Source: USITC. The two vertical lines correspond to the dates of the DoC announcement of AD tariffs (left) and of the ratification of the decision by the USITC (right).

ratification of the USITC in July 2003 (right vertical line), imports plummeted to a monthly average of 56 tons in the second semester of 2003, an 85 percent drop since 2002. These changes in import are consistent with the literature: Staiger and Wolak (1994) document similar drops in U.S. imports during the investigation phase in several antidumping cases and Prusa (2001) estimate overall drops of about 50 percent in U.S. AD-subject imports.

\section{Catfish Farming in the Mekong}

Fishing and aquaculture are prevalent all over Vietnam, a country with a dense river network and hundreds of kilometers of coastal areas. While marine fishing, both offshore and inshore, are important, our analysis focuses on small-scale aquaculture production by Viet- 
namese farmers. Within aquaculture, there are three major fishing activities in the country: freshwater aquaculture (river fishing), brackish water aquaculture (medium-salinity waters as in estuaries) and marine aquaculture (saltwater). Since catfish is a river fish, we will only study freshwater aquaculture.

To investigate the impact of the U.S. antidumping duties on Vietnamese farmers, we focus on households residing in provinces where catfish production is concentrated. We will label these provinces, which are located in the Mekong region of South Vietnam, 'catfish provinces'. Data on fish production by species in Vietnam is not easily available to the public. In order to identify the catfish provinces, we must therefore follow an indirect approach consisting of two strategies. First, we examine the geography of the country and the ecological conditions needed for catfish production across regions. Second, we present supporting information on catfish production by provinces that we obtained from various sources.

Within Vietnam, the production of catfish is geographically concentrated in the Mekong Delta. This is because catfish only develops in relatively flat rivers with sandy soils, a prevalent feature of the Mekong area. The Red River Delta, in North Vietnam, is instead a mountainous region not suitable for catfish, but rather for other fish like carp. The other regions specialize mostly in brackish and saltwater products. Table 1 supports this claim. Based on the description of the sector in World Bank (2005) - a comprehensive report on Vietnam Aquaculture - we assembled evidence on region-specific forms of aquaculture. Two observations stand out. First, freshwater production is relevant in all North Vietnam and, within the South, only in the Mekong where 50 percent of the aquatic output comes from freshwater fishing. In addition, while the Mekong produces tra and basa (along with other fish 
like tilapia and barb) the North, and in particular the Red River, specializes in carp (common, Indian and Chinese). The main brackish aquaculture product is shrimp, particularly in the non-Mekong South, together with mollusks, crabs, mussels, scallops, and clams. Saltwater aquaculture involves mostly grouper and cobia. These observations establish that catfish is only produced in the Mekong region.

Even within the Mekong region, there is considerable heterogeneity in the composition of aquaculture production. While landlocked provinces specialize in freshwater aquaculture, coastal provinces tend to be more heavily engaged in brackish and saltwater aquaculture. Also, suitable river conditions for catfish farming are more prevalent in some provinces than in others. To see why, Figure 2 displays a map of the Mekong area and its provinces. Some Mekong provinces (Kien Giang, Ca Mau, Bac Lieu, Soc Trang, Tra Vinh, and Ben Tre) have extensive marine coastlines. Instead, the provinces of An Giang, Can Tho, Dong Thap, Vinh Long, Long An, and Tien Giang are mostly landlocked. The Mekong river, where catfish thrives, flows down from Cambodia and enters Vietnam at the border between An Giang and Dong Thap. The river then divides into the Hau branch, which crosses the Can Tho province, and the Tien branch, which crosses Tien Giang and Vinh Long provinces. The Mekong finally empties into the sea mostly in the provinces of Soc Trang and Tra Vinh. The catfish habitat is concentrated in the provinces more heavily touched by the Mekong River.

Table 2 includes information on aquaculture production for each province in the Mekong region. ${ }^{8}$ Columns 1 and 4 show the share of freshwater aquaculture in total aquaculture

\footnotetext{
${ }^{8}$ Data have been gathered from difference sources, which include the Ministry of Fisheries (www. fistenet.gov.vn) and seafood industry magazines such as Seafood from Vietnam Magazine (www. seafoodfromvietnam.com.vn) and World of Pangasius (www.worldofpangasius.com.vn).
} 
Figure 2

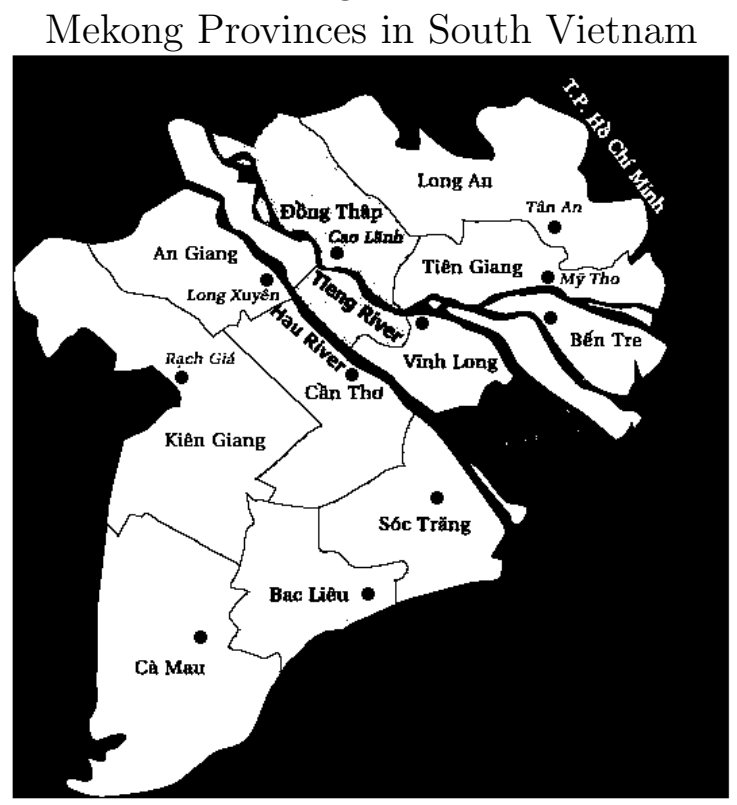

Note: Map of the Mekong provinces.

output in 2002 and 2003. In Dong Thap, An Giang, Vinh Long, and Can Tho, almost 100 percent of the aquaculture production is freshwater aquaculture. The share is much smaller in coastal provinces, where brackish and marine fishing is more relevant (columns 2 and 5). In particular, shrimp is prevalent in Bac Lieu, Ca Mau, and Kieng Giang, which are located on the Southernmost tip of Vietnam (columns 3 and 6). This confirms that landlocked provinces tend to be much more specialized in freshwater aquaculture than coastal provinces. Further, column 7 displays information on the share of provincial catfish production in 2003, calculated from data on total catfish production in the Mekong region. The main producers of tra and basa in 2003 were An Giang, which accounted for 40.2 percent of total production, Dong Thap (15.8 percent) and Can Tho (25.5 percent). While Vinh Long and Tien Giang were also relatively important catfish producers, Soc Trang only contributed 3.1 percent of the total in 2003. All other provinces produced very little (around 1.6 percent) of tra and 
basa in that year. Overall, these data confirm that catfish is indeed mostly produced in landlocked Mekong provinces.

In light of this evidence, our analysis focuses on the six 'catfish provinces' identified above, which we aggregate into two samples (see the last two columns of Table 2). Our core sample, which we call Mekong 4 (M4), comprises the landlocked provinces that almost fully specialize in freshwater aquaculture, namely An Giang, Can Tho, Dong Thap and Vinh Long. For robustness, we also explore results using an alternative sample, which we call Mekong 6 (M6), that adds the provinces of Soc Trang and Tien Giang. These two latter provinces are also engaged in catfish farming, but are significantly diversified into brackish and marine aquaculture as well.

\subsection{The Household Survey Data}

For the empirical analysis, we use panel data from the Vietnam Household Living Standard Surveys (VHLSS). The first round of the VHLSS was carried out in 2001-2002, before the imposition of U.S. tariffs on catfish in 2003. The second round was carried out in August 2004, after the introduction of the trade barriers. The availability of ex-ante and ex-post panel data makes the $\mathrm{AD}$ on Vietnamese catfish an ideal case study.

The VHLSSs were conducted by The General Statistics Office of Vietnam (GSO) with technical assistance from UN Statistics Division, the World Bank and Statistics Sweden. In both surveys, GSO used a stratified two-stage sampling design. The primary sampling units were enumeration areas in urban areas, and supervisor areas in rural areas, identified in the 1999 Population and Housing Census. The surveys are representative at the national level. 
VHLSS'02 surveyed more than 74,000 households while VHLSS'04 surveyed over 44,000. A fraction of this sample forms a panel, with a total of 16,518 households surveyed in both years. The size of the panel is smaller than the initially planned figure of 20,000 , both because of attrition and because errors in recording household identifiers makes it impossible to match some panel households between the two rounds of the survey. Unfortunately, it is not possible to establish which or how many of the remaining 3,482 households are lost from the panel because of attrition or because of the mis-coding. ${ }^{9}$

The VHLSSs comprise several modules with information on demographics, education, employment, health, income and labor supply. There is also an expenditure module, which was however used only for a subsample of the interviewed households, 29,000 in VHLSS'02 and 9,000 in VHLSS'04. In practice, the expenditure module is not usable for our purposes because there are only a few dozen observations in the panel sample of aquaculture households in our focus Mekong provinces. Extensive modules record information on farm activities related to agriculture, livestock and aquaculture. Data include production, sales, input use and investment. The information on aquaculture activities distinguishes between raising and catching fish, shrimp, or all other aquaculture products (like mollusks). It must be emphasized that the data do not explicitly separate catfish from more general fish production. Hence, although in the rest of the paper we will refer to 'catfish income' and to 'catfish households', these are, strictly speaking, 'fish income' and 'fish households'. At the same time, we have shown that catfish production is largely concentrated in the regions relevant

\footnotetext{
${ }^{9}$ Households who form the panel appear to be very similar to the overall sample in the 2002 survey, so differential attrition/miscoding should not be a concern. For instance, the mean income share from fish farming in M4 provinces is 11.2 both among panel households and in the complete 2002 sample. Similarly, per capita income among these households is 3,537 Dong per year in panel households and 3,578 in the full 2002 sample.
} 
for our analysis, in particular in M4 provinces.

Sample size and income levels on the panel sample are reported in Table 3. Panels A) and B) refer to households in the Mekong Delta in the target samples M4 and M6; Panel C includes information on South Vietnam (excluding the Mekong), for comparison purposes. ${ }^{10}$ The table includes figures for fishing households, all rural households (fishing and non-fishing), and all households in the panel data, for both 2002 and 2004. Catfish production is concentrated in the Mekong region. There are 561 and 788 catfish households in the M4 and M6 panel samples, respectively. This is over half of the overall sample in the region and around 60 percent of the total rural sample. These catfish households are the relevant population exposed to the $\mathrm{AD}$ shock on which we base our analysis. Fishing is less prevalent in the rest of rural South Vietnam, where it involves only 384 out of 3185 households (12 percent).

For each of the M4, M6, and South Vietnam (non-Mekong) regions, and for each set of households (fishing, rural, all), we also report in Table 3 the median level of total annual per capita income $(p c i)$ in thousand 2002 Vietnamese Dong and in US PPP dollars. ${ }^{11}$ Income is defined as the sum of all sources of household income including earnings in agriculture (both from sale and home consumption), aquaculture, wages, livestock, silviculture, hunting, nonfarm activities and transfers. The median income levels are very similar for catfish households in the target samples M4 and M6 both in 2002 and 2004. In M4, median pci increases from 3,537 thousand Dong in 2002 to 4,224 thousand Dong in 2004, while in M6 it increases from

\footnotetext{
${ }^{10}$ We exclude North Vietnam from the analysis because of the striking differences in performance between the North and the South resulting from differences in the political environment up to the mid 1980 s. We thank Quy-Toan Do for raising this issue in previous versions of our paper. See also Brandt (2006).

${ }^{11}$ The numbers reported in the table are in real terms and have been deflated by the general price index used to measure inflation in Vietnam as well as PPP series from the World Development Indicators.
} 
3,544 to 4,281 thousand Dong. Note that, despite the AD shock to catfish income, there is sizeable growth in total per capita income in the Mekong. These growth rates are, however, slightly lower than the average growth rate in $p c i$ at the national level based on VHLSS data. Catfish households are relatively better-off than the rest of the households in the Mekong. For instance, in 2002, the median pci of fishing households was around 4.8 percent higher than among all rural households and 4.5 percent higher than the overall median in the Mekong. Note that Mekong households are also better off than South Vietnamese households.

To present an overview of the sources of income in the region, we report in Table 4 the share of income derived from different economic activities in the two target samples M4 and M6. Catfish households rarely specialize in fishing and are instead diversified into various economic activities, including wage labor, agriculture (both for sale in the market and for home consumption) and miscellaneous farm activities (including poultry, livestock, odd-job farm services, and silviculture). At the same time, these households were only marginally involved in other aquaculture activities, such as shrimp or marine fishing. In Table 4, we see that the share of catfish income declined in the Mekong area after the imposition of the antidumping duties in 2003. Before the AD shock, the average share of income derived from catfish in M4 was 11.2 percent. In 2004, we observe the share dropped by almost 40 percent, to 6.8 percent. Similarly, the share of catfish income in M6 decreased by about one third, from 9.6 percent in 2002 to 6.5 percent in 2004 . 


\section{Anti-dumping Duties: Impacts on Household In-}

\section{come}

In this section, we describe our empirical strategy and we discuss our estimates of the impact of the $\mathrm{AD}$ duties on household income. In section 5, we provide a more detailed documentation of household adjustments in the income generation process among fishing farms in the Mekong delta.

\subsection{Empirical Strategy}

The target samples in our analysis include households residing in provinces of the Mekong regions where catfish production is concentrated - the M4 and M6 samples defined above. In addition, we use the sample of households in South Vietnam for falsification purposes as well as for robustness. As already explained, we explicitly exclude provinces in Northern Vietnam because of the historical differences with the South (Brandt, 2006).

In all our models, our estimation strategy relies on comparing household outcomes before and after the introduction of the U.S. AD duties across households with different levels of exposure to the shock. Let $Y_{h, t}$ be the outcome of interest in year $t, t=2002,2004$. In our baseline model, we include all households (i.e., fishing and non-fishing rural farms) in the target regions, M4 and M6, and we estimate the following regression for the outcome change

$\Delta \ln Y_{h}=\ln Y_{h, 2004}-\ln Y_{h, 2002}:$

$$
\Delta \ln Y_{h}=\phi+\phi_{0} 1\left(s_{h}^{c}=0\right)+\Delta \mathbf{x}_{h}^{\prime} \beta+\gamma \ln y_{h, 2002}+g\left(s_{h}^{c}\right)+\epsilon_{h},
$$


where $\mathbf{x}_{h t}$ is a vector of household controls, $\ln y_{h, 2002}$ is the log of the initial level of household income and $s_{h}^{c}$ is the initial share of income derived from catfish farming. In (1), $\phi$ is the common time trend for fish farmers and the coefficient $\phi_{0}$ allows explicitly for the presence of a different trend for households with no involvement in aquaculture (measured by $\phi+$ $\left.\phi_{0}\right)$. It is important to allow for such difference in trends because catfish farming requires the availability of distinctive land characteristics which may be associated with unobserved differences in income trends (Brandt, 2006). ${ }^{12}$ The function $g(\cdot)$ allows for non-linearities in the impact of exposure to the shock on outcome changes. We discuss below estimates from a quadratic functional form as well as semi-parametric estimates where the function $g($.$) is$ left unspecified.

The availability of panel data allows for the presence of year fixed effects $(\phi)$ and household fixed effects, where the latter have been differenced out in (1). The inclusion of a year effect controls for overall trends and aggregate shocks which may have affected all households equally. The household fixed effects absorb time-invariant unobserved heterogeneity at the farm/household level such as preferences, farming ability, land quality, or other pre-shock differences in aquaculture production. In addition, the household fixed effects embed regional, district or otherwise local effects. The vector $\mathbf{x}_{h t}$ includes a list of household-specific controls, that is, household size, demographic composition, marital status and education of the head. The inclusion of $\ln y_{h, 2002}$ among the regressors allows us to control for differences in trends that are a function of initial (log) income (Banerjee et al., 2007).

Exposure to the $\mathrm{AD}$ shock is measured by $s_{h}^{c}$, that is, the share of total household income

\footnotetext{
${ }^{12}$ We also estimate models using only fishing farms (with $s_{h}^{c}>0$ ). Further, in section 4.3 below, we estimate a more general model that allows for different trends at different exposure levels.
} 
in 2002 derived from fish farming. In Section 3, we have argued that such variable is a good approximation for the share of income from catfish farming, especially in M4 regions. ${ }^{13}$ Note that our estimates are a measure of the differential impact of the shock at different levels of exposure. It follows that an estimated negative impact of $s_{h}^{c}$ on the change in $\ln Y_{h}$ does not literally indicate a predicted decline in the outcome, but rather measures the impact on the rate of growth relative to a household whose share of income from catfish farming is positive but close to zero. ${ }^{14}$ In the remaining of the paper we will refer to such differential changes as to "relative income losses."

Figure 3 plots an estimate of the distribution of initial catfish shares (conditional on catfish participation), using Gaussian Kernel methods, for sample M4. The distribution of catfish shares is clearly unimodal and right-skewed. The mode is close to 0.025 , while mean and median are respectively 5.5 and 11.2 percent. To reveal different AD effects at different levels of exposure, below we evaluate the estimated impact of the $\mathrm{AD}$ at different values of $s_{h}$. Using data from M4, we define three levels of exposure: low, at the median share (5.5 percent); medium, at the mean share of 11.2 percent; high, at a level equal to the median share among farmers above the sample mean (around 20 percent). These exposure levels are

\footnotetext{
${ }^{13}$ We have already shown that fish income shares are good proxies for catfish income shares in M6 and especially M4 provinces, and below we develop several validation exercises to further support this claim. Nevertheless, the fact that we use $s_{h}^{\text {fish }}$ as a proxy for $s_{h}^{\text {catfish }}$ has implications for the interpretation of our results. In all our regressions, we estimate the predicted change in the growth on an outcome (income, investment, etc.) associated with differences in exposure, measured by $s_{h}^{\text {fish }}$, with models such as $\Delta \ln Y_{h}=$ $\phi+g\left(s_{h}^{f i s h}\right)+u_{h}$ (abstracting for all other regressors). Since $s_{h}^{f i s h}$ is a proxy, we have that $s_{h}^{f i s h}=f_{h}\left(s_{h}^{\text {catfish }}\right)$. As long as $f_{h}^{\prime}()>$.0 , an assumption that we argue is correct in M4 and M6 provinces, our results can be interpreted as indicating the impact on the growth rate of $Y_{h}$ of an increase in the share of income from catfish. However, note that the exact quantification of the slope would require knowledge of the shape of the function $f($.$) .$

${ }^{14}$ If exposure to the shock were binary, the results in this specification could be intuitively interpreted as difference-in-differences (DD), with identification relying on the comparison of changes in outcomes between households with high versus low exposure.
} 
Figure 3

Catfish Income Shares in 2002

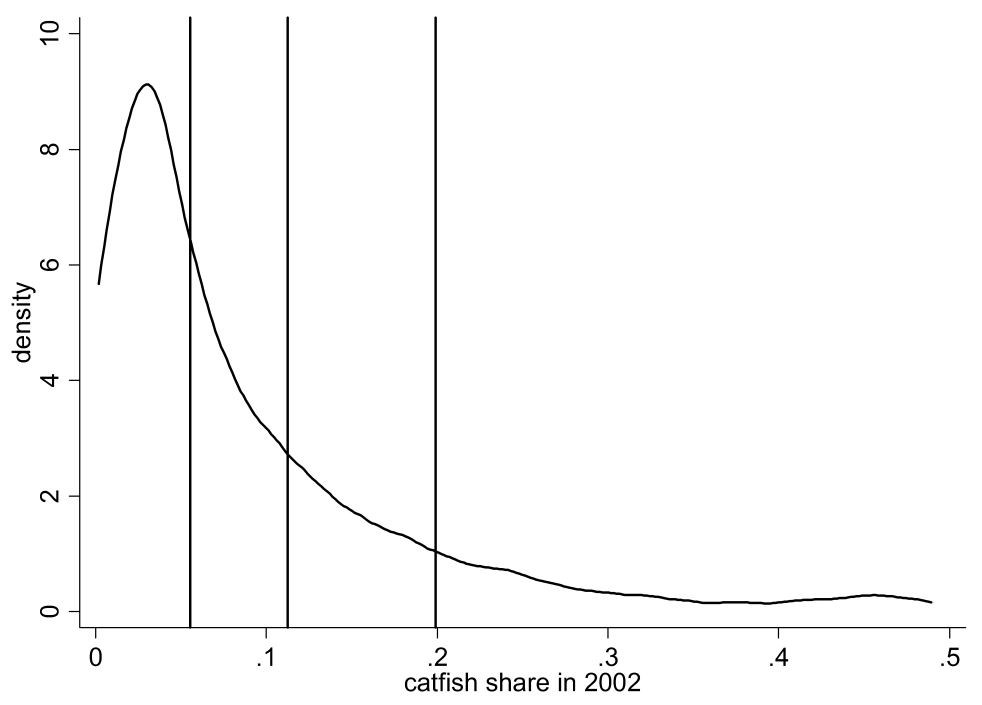

Note: non-parametric estimates of the density of catfish income shares in 2002 using a Gaussian Kernel and the standard optimal bandwidth. The sample is M4, the Mekong provinces of An Giang, Can Tho, Dong Tha, and Tra Vinh. The vertical lines represent the median catfish share (the leftmost line), the mean share (the center line) and the median share, conditional on producing more than the mean (the rightmost line).

represented by the three vertical lines in Figure 3.

\subsection{The Impact on Household Income}

We begin by estimating the impact of the $\mathrm{AD}$ shock on household income. ${ }^{15}$ We present separate results for total and per capita household income (which includes all sources of income) and for net income (total income net of the cost of inputs in farm activities). Our basic specification adopts a quadratic polynomial on the initial shares to estimate $g(\cdot)$. For robustness, we also estimate a more general and flexible partially linear semi-parametric model as in Robinson (1988).

\footnotetext{
${ }^{15}$ As a reminder, expenditure-based indicators cannot be used as outcomes because the expenditure modules were filled only by a small sample in our panel of aquaculture households in the Mekong.
} 
Results from the quadratic regression model are in Panel A of Table 5. We report the impact on total household income in M4 (column 1) and in M6 (column 2). The corresponding results for per capita household income are in columns 3 and 4 and, for net income, in columns 5 and 6 . All our estimates for the three outcomes are negative and statistically significant at the 1 percent level. Looking at M4, we find that a farmer with the median pre-shock share suffers a relative income loss of 8.7 percent (column 1 of Panel A). A farmer with an average pre-shock share suffers instead a relative income loss of 15.8 percent, while the relative loss for a high-exposure farmer is 23.6 percent. The impact on per capita income is similar, 8.9, 16.2 and 24.1 percent, respectively (column 3). Instead, the impact on net income is slightly larger: 10.5 percent for low-exposure, 18.8 percent for average-exposure, and 27.6 percent for high-exposure (column 5).

When we estimate model (1) using the expanded M6 sample, the impact on each outcome is lower in magnitude but still negative and statistically significant at the 1 percent level. In column 2 of Panel A, the relative decline in total household income is 7.1 percent for lowexposure farmers, 12.9 percent for the average farmer, and 19.2 percent for highly-exposed farmers. The relative losses in per capita income are equal to 7.3, 13.2 and 19.6 percent, for low-, average-, and high-exposure households, respectively (column 4). Finally, the relative declines in net income are estimated at 8.9, 16.0, and 23.6 percent for the three exposure levels (column 6). The fact that the magnitude of the estimates is lower when the sample is expanded to include households in M6 relative to M4 was to be expected. In fact, as shown in Table 2, fish farming was almost completely represented by freshwater aquaculture (such as catfish) in M4, while it represented a significantly lower share in Tien Giang and Soc 
Trang, the two added provinces in M6. In other words, $s^{c}$ is a better proxy for exposure to the $\mathrm{AD}$ shock in M4 than in M6 provinces and so we would expect the estimated impacts to be attenuated in this second sample.

As an alternative specification, we estimate a model analogous to equation (1) but where we include only households involved in aquaculture, that is, households with $s_{h}^{c}>0$. Results from this model are similar to those discussed above, for all levels of exposure, for all three outcomes and for both M4 and M6. ${ }^{16}$ As an example, consider the impact on total household income in M4. The relative income losses are 6.2 percent for low-exposure farmers (vis-à-vis 8.7 percent), 11.3 percent for mean-exposure farmers (vs. 15.8 percent), and 17 percent for high-exposure producers (vs. 23.6 percent).

In Panel B of Table 5, we estimate the exposure function $g(\cdot)$ non-parametrically. ${ }^{17}$ In general, our findings are similar to those from the quadratic model. For instance, in M4 the impact on total household income change is 9.4, 16.9, and 24.3 percent, at low-, mean- and high-exposure respectively. In M6, the corresponding figures are 7.1, 13.5, and 20.5 percent. The estimated impact on the rate of growth of per capita and net income is also similar to the quadratic specification. ${ }^{18}$

We can use our semi-parametric estimates to plot the overall shape of the function $g(\cdot)$, which reveals the different impact for households across different catfish shares. The results

\footnotetext{
${ }^{16}$ See Panel A of Table A1 in the Supplemental Web Appendix, available at the Review's Web site and at the authors personal Web sites.

${ }^{17}$ We estimate the partially linear model of Robinson (1988) with locally weighted non-parametric regressions. Since in this model the scale of the function $g(\cdot)$ cannot be recovered, we adopt the normalization $\lim _{s \rightarrow 0} g\left(s^{c}\right)=0$, as in the quadratic specification. The standard errors are computed using the theoretical formulas reported in Pagan an Ullah (1999).

${ }^{18}$ The results for the model based only on aquaculture households (reported in Panel B of Table A1 in the Supplemental Web Appendix) are comparable as well.
} 
are in Figure 4. Panel A shows estimates for total income, Panel B for per capita income, and Panel $\mathrm{C}$ for net income. For each outcome, the graph on the left is the estimate for the M4 sample while the one on the right refers to the M6 sample. Consistent with the parametric estimates, the shape of the function $g$ is non-linear, with a negative sloped and convex. Given that the quadratic model approximates well the shape of the function $g($.$) ,$ in the remaining of the paper we only focus on the parametric estimates.

\subsection{A Validation Exercise}

Our identification strategy relies on the fact that exposure to the AD shock is well approximated by the share of income from fish farming (which, in turn, is a close approximation to the share from catfish farming in M6 and especially M4 provinces). Central to this hypothesis is that, conditional on household fixed effects and the other controls included in the model, households with different involvement in fish farming would not have been characterized by a systematically different time trend, were it not for the presence of the $\mathrm{AD}$ tariff. If that were instead the case, the impact of the AD tariffs would be confounded by such differences in unobserved trends. ${ }^{19}$ To probe further this identification strategy, we perform a validation exercise where we also include in models (1) and (??) observations from non-Mekong provinces in South Vietnam (arguably the best candidates for this exercise). This strategy provides a test of our hypothesis that the results are not driven by unobserved differences in trends at different fish income shares $s^{c}$. In fact, we find that the predicted changes in

\footnotetext{
${ }^{19}$ One potential threat to our assumption is the outbreak of the avian flu in 2004. Note, however, that while the initial outbreak took place in January 2004, the epidemic only became sizeable after August 2004 and thus after the collection of data for the 2004 round of the VHLSS. The outbreak of the avian flu is then unlikely to be an important concern.
} 
Figure 4

Antidumping Impacts on Household Income

A) Total Household Income
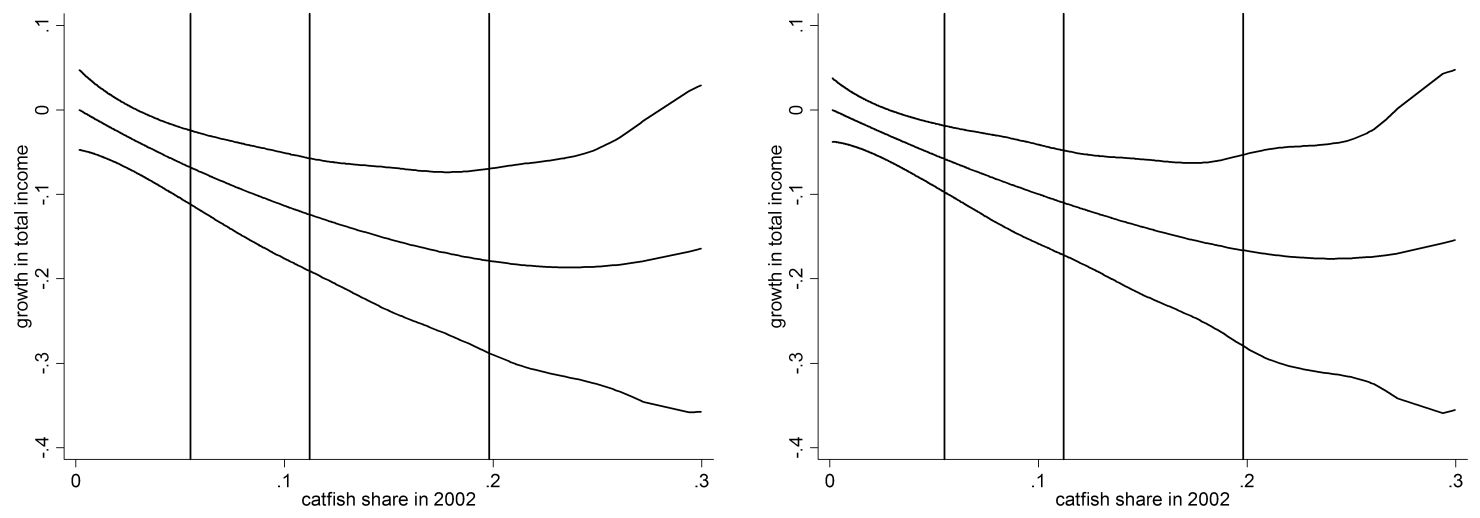

B) Per Capita Household Income
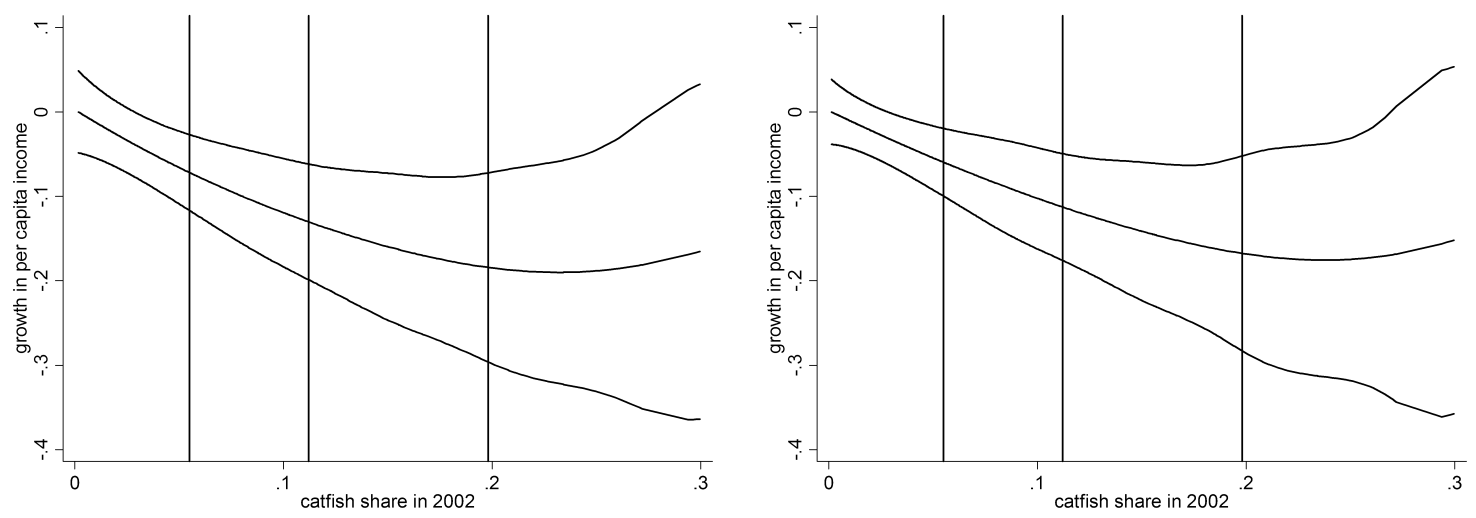

C) Total Net Household Income
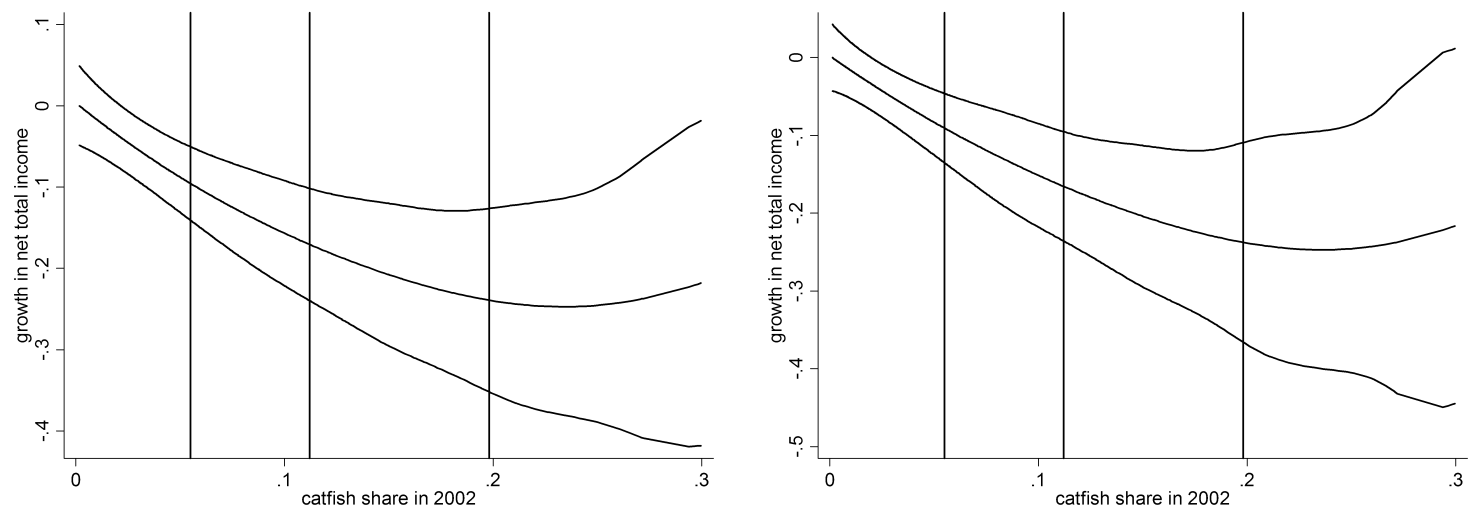

Note: Own calculations based on the panel of aquaculture households from the VHLSS (2002 and 2004). The estimates represent the relationship between the growth rate in total household income (panel A), per capita household income (panel B) and total net/disposable income (panel C) and the exposure to the U.S. antidumping shock (measured by the share of income derived from catfish) relative to a household with marginal exposure. The graphs on the left are estimated using the M4 sample (which includes the Mekong provinces of An Giang, Can Tho, Dong Thap and Vinh Long); the graphs on the right use instead the M6 sample (which adds Soc Trang and Tien Giang). 
outcomes for households in non-Mekong South Vietnam are positive (and mostly small and not significant). Nevertheless, the inclusion of non-Mekong South Vietnamese fish farmers in the estimation allows us to control for any South Vietnam aquaculture-specific trends (even if they are relatively small). ${ }^{20}$

Concretely, the modified model becomes:

$$
\begin{aligned}
\Delta \ln Y_{h} & =\phi+\phi_{0} 1\left(s_{h}=0\right)+\Delta \mathbf{x}_{h}^{\prime} \beta+\gamma \ln y_{h, 2002}+\alpha_{0} M_{h}+\alpha_{1} s_{h} \times M_{h}+\alpha_{2} s_{h}^{2} \times M_{h} \\
& +\gamma_{1} s_{h}+\gamma_{2} s_{h}{ }^{2}+\phi_{2} 1\left(s_{h}=0\right) \times M_{h}+\epsilon_{h},
\end{aligned}
$$

where $M_{h}$ is a dummy which takes a value of one for target households (those residing in M4 or M6) and $s_{h}$ is the share of income from fish farming. Note that the model includes both a binary variable equal to one for households with $s_{h}=0$ as well as its interaction with $M_{h}$, so that non-aquaculture households are allowed to have region-specific trends. Under our identifying assumptions, the impact of the AD at a given exposure $\bar{s}$ for Mekong catfish producers is then $\alpha_{1} \bar{s}+\alpha_{2} \bar{s}^{2}$. We expect estimates of these effects to be negative and comparable to those reported in Table 5. The change for South Vietnam fishing households is instead $\gamma_{1} \bar{s}+\gamma_{2} \bar{s}^{2}$.

The results are displayed in Table 6. Estimates of model (2) for Mekong farms are shown in Panel A, and for Southern (non-Mekong) farms, in Panel B. Two observations emerge from these results. First, the estimated impact on Mekong catfish farmers is comparable, although larger in magnitude, to our findings reported in Table 5, for all three income

\footnotetext{
${ }^{20}$ Intuitively, if exposure were a binary variable, this approach would be equivalent to a triple difference estimator, where identification derives from the comparison of two DD estimates between two groups (in our case, Mekong vs. rest of South Vietnam.
} 
outcomes. For example, in M4 (Panel A), column (1), the relative income losses are 12.8 percent, 22.9 percent, and 33.8 percent for low-, mean-, and high-exposure, respectively. ${ }^{21}$ Second, the results for non-Mekong Southern farms show that, for all outcomes and for all levels of exposure, there is no evidence that the pre-AD fishing shares are negatively associated with income growth. Indeed all estimated impacts for these farms are actually positive and in some cases large and statistically significant. The fact that such estimated impacts are positive is in fact the reason why the estimates for Mekong households become larger in magnitude than the corresponding figures in Table 5. Overall, this falsification experiment helps validate our empirical strategy: while a relatively large involvement in fish farming was associated with a relatively higher rate of income growth in the non-Mekong South (although in most cases not statistically significant), the opposite was true in M4 and M6 provinces, where involvement in freshwater aquaculture is a proxy for catfish farming. Similar results are obtained from variations of this validation exercise where the comparison sample comprises either Mekong households (not in M6) or both non-Mekong South farms and non-M6 Mekong farms.

Before turning to study in detail how catfish farmers adjusted to the AD shock, we should mention that our estimates reflect the impact of the anti-dumping after allowing for different economy-wide responses to the shock. One important such response is trade deflection, that is, the shift of exports to other non-U.S. markets (Bown and Crowley, 2007). For Vietnamese catfish, trade deflection is hard to establish or to rule out, due to lack of data. ${ }^{22}$ Some

\footnotetext{
${ }^{21}$ The estimated relative losses from a model using only aquaculture households, reported in Table A2 of the Supplemental Web Appendix, are also comparable.

${ }^{22}$ The Vietnamese government does not release export data on catfish, while publicly available data on COMTRADE is disaggregated up to the level of frozen fillets, but not specifically catfish.
} 
evidence is offered by COMEXT data on European Union imports, which indicate that imported quantities of tra and basa from Vietnam increased by 78 percent between 2002 and the first semester of $2004 .{ }^{23}$ Another factor which may have muted the negative impact of the U.S. tariffs is government policy. In July 2003, the Vietnamese ministry launched the Fund for Development of Aquaproduct Export Markets to support aquaculture product exporters of fish. Further, Agifish and other fish exporters launched a campaign to promote domestic consumption of basa and tra fish. While these initiatives could have helped catfish producers directly, they may have also created spillovers on non-catfish household activities.

\section{Household Adjustments to the Anti-Dumping Mea-}

\section{sures}

In the previous section, we reported reduced-form estimates of the impact of the $\mathrm{AD}$ shock on household income. These are, ultimately, the relevant quantities needed to assess the welfare impact of the trade shock on Vietnamese Mekong households. These impacts, however, do not directly describe the mechanisms through which households were affected, mechanisms that we set out to uncover in this section. This exercise should provide useful insights about the way households cope with large trade shocks, thus allowing us to enrich the still small literature that analyzes the impact of international trade at the micro level in developing countries.

A drop in catfish prices has a direct, first order welfare impact via changes in catfish

\footnotetext{
${ }^{23}$ According to data released by the Vietnamese government, the European Union accounted for 29.6 percent of Vietnamese catfish exports in 2004.
} 
income. ${ }^{24}$ These first order effects can be measured with data on catfish income shares, by using a procedure that has become routine in the literature after the pioneering work of Deaton (1989) - especially when only cross-sectional data are available. Households can react to a large change in the relative price of an important agricultural output such as catfish by reallocating resources away from catfish farming and into agriculture, or may reduce farm labor in favor of off-farm labor.

In Deaton's approach, the welfare impact of these adjustments is assumed to be negligible. This is because if the first order conditions in production hold for each household, even though all sources of income may change, the marginal return of inputs should be identical across different activities. Hence, in the margin, these effects net out in the welfare calculations.

However, the standard first order approximation can be inaccurate if there are missing markets or other distortions, or if the price change is large enough that general equilibrium effects and second-order effects become important. For instance, general equilibrium effects may arise if changes in catfish prices cause changes in the local derived factor demands in the region. In the Mekong, catfish sales are a major source of cash income and lower catfish prices are thus associated with lower demand for products and services produced locally. This, in turn, may reduce the income earned in non-catfish activities, such as agriculture, off-farm work or poultry and livestock raising. In consequence, a catfish producer will be affected directly by lower catfish prices and revenues and also indirectly by these spillovers to local markets. On the other hand, local substitution in consumption away from poultry

\footnotetext{
${ }^{24}$ Note that while it is not obvious that the imposition of U.S. AD duties on Vietnamese catfish should bring about a decline in prices (in particular if Vietnam was originally involved in dumping), there is ample evidence of such price decline. A comprehensive U.K. Department for International Development report, for instance, shows that in An Giang basa and tra prices declined by 25-26 percent during 2003. See Nguyen, Nguyen, and M. Philips (2004).
} 
and into now cheaper catfish could dampen the direct impact of the AD.

In addition, second-order effects may become important if complete markets do not exist, a condition which will generate wedges between shadow and market prices that can affect the first order calculations. More specifically, our study areas in Vietnam are characterized by two major market imperfections. First, there is ample evidence of limits to off-farm employment opportunities which generate a discrepancy between the exogenous market wage and the endogenous shadow family wage (Nguyen, Nguyen and Phillips, 2004; Seshan, 2006; Le, 2008). Le (2008, 2009) builds on Jacoby (1993) and estimates six-fold differences between shadow and market wages, a finding that is consistent with large limitations to off-farm employment. $^{25}$ In addition, Do and Iyer (2008) provide strong evidence of credit constraints. Credit market imperfections can create a cash-in-advance constraint where the cash income earned from catfish sales is needed to finance household investments, not only in aquaculture but also in agriculture. In this scenario, changes in catfish prices may affect input choices and then restrict the production possibilities in current and future seasons. Note that these imperfections can be interdependent. For instance, the liquidity constraint that forces households to rely on available cash income to purchase inputs can be amplified by the lack of cash-earning opportunities from labor outside the farm.

We can better illustrate these mechanisms as follows. Assume, for simplicity, that households are engaged in two economic activities, catfish and agriculture. Total income is $y_{h}=y_{h}^{c}+y_{h}^{a}$, the sum of catfish income $y_{h}^{c}$ and agricultural income $y_{h}^{a}$. In turn, these are equal to the product of prices $p$ and quantities $q$ so that $y_{h}=p_{h}^{c} q_{h}^{c}+p_{h}^{a} q_{h}^{a}$. The change in

\footnotetext{
${ }^{25}$ Benjamin (1992) describes how the lack of complete labor markets leads to non-separability in consumption and production decision for agricultural households.
} 
household income that would take place after a drop in $p^{c}$ is

$$
d y_{h}=q_{h}^{c} d p_{h}^{c}+p_{h}^{c} d q_{h}^{c}+p_{h}^{a} d q_{h}^{a}+q_{h}^{a} d p_{h}^{a} .
$$

The first term on the right-hand side is the first order approximation in Deaton (1989). The second and third term comprise household production adjustments in aquaculture and agriculture. With lower catfish prices, farmers produce less catfish and more agricultural products (so that $d q_{h}^{c}<0$ and $d q_{h}^{a}>0$ ). Typically, these two terms cancel out if marginal products are identical across activities, but can be non-zero with distortions. The last term illustrate a market general equilibrium effect that would occur if the price of the agricultural good changes in response to the catfish anti-dumping. This arises if, for instance, lower catfish income or local substitution effects in consumption lowers the local demand for agricultural products. In the remaining of this section, we study the reaction to the AD shock of different components of income.

We begin by assessing the response of income from catfish farming to the AD shock: we estimate model (1) using the change in (log) fishing income as the dependent variable. Results are in columns 1 and 2 of Table 7 (Panel A). ${ }^{26}$ As expected, the anti-dumping had a large impact on fish income at all levels of exposure and especially for highly-exposed farmers. For instance, in the M4 sample, the relative catfish income loss is 36.7 percent for low-exposure farmers, 57.7 percent for the average farmer, and 74.0 percent for the highexposed farmer (the impacts in M6 are 39.8, 61.6 and 77.6 percent respectively). In Panel

\footnotetext{
${ }^{26}$ Note that, with this outcome, we cannot include households not involved in fish farming in 2002 , because for them the dependent variable is missing.
} 
B, we report the estimated impacts for Mekong fish farmers when we perform the same validation exercise as in Table 6, by including aquaculture households from non-Mekong Southern provinces as well. All estimates remain large, negative and significant at the 1 percent level, although their magnitude decreases by about one quarter. This is because the inclusion of Southern provinces allows us to control for fish-specific trends and to separate the actual impact of the $\mathrm{AD}$ shock from any mechanical negative correlation between growth in fishing income and initial fishing income shares.

We can use the estimated changes in catfish income to predict the magnitude of the implied first order change in total household income that we should have observed if all other sources of income had remained unchanged. Keeping agricultural income and prices constant, we have that $d \ln y_{h}=s_{h}^{c} d \ln y_{h}^{c}$. By multiplying the estimated changes in catfish income in columns 1 and 2 of Table 7 by the pre-shock catfish shares, we estimate relative losses in total income $y_{h}$ of 2.0, 6.5 and 14.8 percent for low-, average- and high-exposure farmers. These magnitudes are smaller than the estimated relative losses in total income reported above. For instance, in Table 5, our estimates were equal to 8.7, 15.8, and 23.6 percent for the three levels of exposure in M4. These differences are likely accounted for by changes in non-catfish sources of income that are induced by spillovers from the AD shock.

To explore this hypothesis, we examine the indirect impact of the AD shock on incomegenerating activities other than catfish income. Major sources of household income are wage income, agricultural sales, agricultural own-production, and miscellaneous farm activities (poultry, farm services and livestock). Results are in columns 3-10 of Table 7, where estimates in Panel A corresponds to regressions using all observations (aquaculture and non- 
aquaculture) in the Mekong. ${ }^{27}$ We find little or no evidence that the anti-dumping shock caused changes in household income earned from wage labor (columns 3 and 4), from the sales of agricultural product (columns 5 and 6) or from the value of production for home consumption (columns 7 and 8). Most estimated impacts, at all level of exposure, are statistically insignificant, although in some cases the point estimates are relatively large.

There is evidence of a decline in income from miscellaneous farm activities such as poultry, livestock, and farm services (columns 9 and 10). For instance, in column 9 of Panel A (M4, all farmers), the relative decline in income from these activities is 22.5 percent for low-exposure farmers, 37.9 percent for mean-exposure farmers, and 51.8 percent for high-exposure farmers. Similar impacts are estimated using catfish farms only (Supplemental Web Appendix). The local demand for these products and services could have been affected not only by lower cash income from catfish sales but also by a substitution in consumption away from poultry and into cheaper catfish. ${ }^{28}$

To further investigate the mechanisms that led to these responses in different income sources, we study changes in hours worked and in investment. Results are in Table 8; in Panel A, we use all Mekong households, while in Panel B we also include all households from non-Mekong Southern provinces. We begin by inspecting the impact on hours worked off-farm for wage, in columns 1 and 2. The results, which are consistent with the lack of

\footnotetext{
${ }^{27}$ We obtained comparable results from a model using only aquaculture observations. See Table A3 of the Supplemental Web Appendix.

${ }^{28}$ It should be noted that there are differences in the samples used in different regressions within this section. This is because not all households in the core sample (i.e., the pre-shock aquaculture producers in 2002) report positive amounts for all the dependent variables analyzed in this section. An obvious example is fish income, which is not reported by pre-shock producers who abandoned the market before 2004. The differences in sample size raise concerns that our inferences from Tables 5 to 7 could be based on potentially non-comparable samples. In Appendix 2, we carry out a series of robustness checks and we argue that the results are not driven by different samples used in the regressions.
} 
adjustment in wages documented above, reveal that hours worked off-farm were not affected by the $\mathrm{AD}$ shock. This suggests that wage income did not respond mostly because households did not, or perhaps could not, increase labor supply to the local labor market. The result is consistent with the evidence of limited opportunities for off-farm employment in Vietnam documented by Nguyen, Nguyen and Phillips (2004), Seshan (2006), and Le (2008, 2009). Also, since neither off-farm wage income nor hours worked off-farm were affected by the AD shock, we can conclude that hourly wages did not respond either so that spillovers via local labor markets in non-catfish activities do not appear to have played an important role. ${ }^{29}$

In Columns 3 to 10 of Table 8, we examine rates of growth of different forms of investment, defined here as expenditures in productive activities. The Vietnam Household Living Standard Surveys compiles detailed information on investment expenditures in agriculture, aquaculture, silviculture, livestock, farm services and other activities. In the target samples (M4 and M6), over half of these expenditures on productive inputs is allocated to agriculture. Aquaculture absorbs around 20 percent, livestock, farm services and silviculture, 19 percent, and other activities around 10 percent. In columns 3 and 4, we report sizeable relative declines in catfish investment. In M4, the relative decline in catfish input expenditures in low-exposure households is 28.3 percent, while the figure is 46.4 percent for medium-exposure households and 61.9 percent when exposure is high (all estimates are statistically significant at the 1 percent level). Similar results are estimated in the M6 target sample, or when households from the non-Mekong South are included (columns 3 and 4 in Panel B). These findings are consistent with cuts in aquaculture activities following the AD shock. Moreover,

\footnotetext{
${ }^{29}$ In results not reported, we tested this by computing a measure of hourly wages (total wage earning divided by total hours) and found very small and statistically insignificant effects at all levels of exposure.
} 
the results suggest large supply (quantity) responses to the shock.

There is little evidence, instead, that households adjusted total investment following the catfish shock. Our point estimates in columns 5 and 6 are always negative, but they are small and we cannot reject the hypothesis that they are equal to zero. When we perform the usual validation by including households from the non-Mekong South (Panel B) the point estimates become positive, but they are again small and very imprecisely estimated, so that even in this case the null of no change for catfish farmers in Mekong cannot be rejected at standard levels. In contrast, there is evidence that households relatively more involved in catfish farming saw faster rates of growth in input expenditures in agriculture. In columns 7 and 8 of Table 8 , in panels $\mathrm{A}$ and $\mathrm{B}$, the relative growth in expenditures in agricultural inputs is positive, large, and increasing with exposure. Finally, we find that the growth in input expenditures in miscellaneous farm activities (livestock, poultry, farm services) was lower for households more exposed to the AD shock. The estimates in columns 9 and 10 are negative and large, but they are not precisely estimated and we cannot reject the null of no relative decline in this type of investment across levels of exposure. ${ }^{30}$

This analysis of the impacts on income sources and investment provides useful insights on household adjustments, especially in terms of agricultural production, a major activity in the Mekong. We uncover two opposing forces at play. On the one hand, there was little overall response in agricultural earnings, both for sale and for home consumption, following the catfish AD shock. However, the pattern of changes in investments shows clear evidence of substitution towards agricultural inputs after the shock. We speculate that these two re-

\footnotetext{
${ }^{30}$ These results are robust to the exclusion of non-aquaculture households. See Table A4 of the Supplemental Web Appendix.
} 
sponses are the result of potential negative market spillovers (whereby lower catfish income led to declines in agricultural activity in the region) matched by a substitution of household production away from catfish and into agriculture. Ultimately, the catfish shock forced Mekong farmers to shut off catfish production and expand agriculture to maintain the value of agricultural production in the presence of negative local market spillovers. Several pieces of supplementary evidence support these conclusions. First, as in many developing countries, production of agricultural products, especially for home consumption, provides a safety net to protect against income shocks. In this setting, an expansion of agriculture, especially rice production in the Mekong, is not surprising. Second, negative local spillovers have been documented in various reports. Nguyen, Nguyen, and Philips (2004), for instance, provide several accounts based on interviews in An Giang province (the main catfish province in the Mekong) of large losses in catfish and non-catfish activities alike. Likewise, Tu and Nguyen (2004) describe inter-sectoral linkages in the Mekong delta. Third, the 2004 VHLSS questionnaire included questions on major hazards constraining household production that we can use to check the role of prices. About 56 percent of Mekong farmers reported low prices (in general) as one of the "three most frequent difficulties faced in production/business." While we cannot be sure from these questions that low prices are due to the AD shock, these data are at least consistent with the existence of negative general equilibrium effects on prices throughout the local economy. 


\section{Conclusions}

Following an anti-dumping lawsuit, the United States imposed tariffs on imports of catfish from Vietnam in June of 2003. These tariffs, which ranged from 37 to 64 percent, led to sharp declines in Vietnamese exports of catfish to the U.S. market. At that time, the United States was the main destination market for Vietnamese catfish, a product which constitutes an important source of income for thousands of households in the Mekong delta of South Vietnam. These facts, together with the availability of a panel data of Vietnamese households for 2002 and 2004, allow us to provide a rich ex-post analysis of the impact of antidumping policies on household behavior.

We have studied impacts on household income and found that, over the 2002-2004 period, the rate of growth of income was significantly lower among households relatively more involved in catfish farming. In addition, we have explored how catfish households adjusted to a large trade shock in a scenario of limited off-farm labor opportunities. We find that the slower rate of income growth among fish farmers in areas where catfish production was concentrated was explained not only by a sharp relative reduction in income from fish farming but also by a reduction in the growth of income from miscellaneous farm activities. This observation is consistent with the existence of spillovers of the $\mathrm{AD}$ measures on economic activities different from those (catfish) directly impacted by it. Finally, although we do not find evidence that the growth in total investment was slower among catfish farmers, there is clear evidence that households moved away from fish farming and re-allocated investment towards agriculture. Overall, our results provide an uncommonly detailed account of the complex micro-economic impact of trade policies on the livelihood of households involved in 
the primary sector of a developing country.

\section{Appendix 1: Robustness to Different Samples}

In most of the regressions reported in section 5, sample size change. This is because not all households in the sample report positive numbers for all the variables analyzed. An obvious example is fish income, which is not reported by pre-shock producers that dropped out of the market by 2004. These differences in sample size raise concerns that our inferences from Tables 7 and 8 are based on potentially non-comparable samples. To shed some light on this issue, we re-estimated the model for changes in income (total, per capita, and net) for the various (selected) sample sizes in Tables 7 and 8 and we compared the results with those for the core samples (from Tables 5 to 6 ). If these results are similar across samples, then we can claim that our inferences based on the selected samples are unlikely to be driven by the differences among the samples. After performing this exercise, we find in general that the impacts on income are indeed similar for all alternative samples. As an example, we report the results for total income, net of input purchases, in Table A1, for samples varying by sources of income, labor supply, and various input purchases. We find that the impact on income are very similar across samples.

\section{References}

Banerjee, A., S. Cole, E. Duflo, and L. Linden, "Remedying Education: Evidence from Two Randomized Experiments in India," Quarterly Journal of Economics, 122:3 (2007), 1235-1264.

Benjamin, D., "Household Composition, Labor Markets, and Labor Demand: Testing for Separation in Agricultural Household Models," Econometrica, 60:2 (1992), 287-322.

Blonigen, B. and C. Bown, "Antidumping and Retaliation Threats," Journal of International Economics, 60:2 (2003), 249-273.

Blonigen, B. and S. Haynes, "Antidumping Investigations and the Pass-Through of Exchange Rates and Antidumping Duties," American Economic Review, 92:4 (2002), 1044-1061.

Blonigen, B. and J. Park, "Dynamic Pricing in the Presence of Antidumping Policy: Theory and Evidence," American Economic Review, 94:1 (2004), 134-154.

Blonigen, B. and T. Prusa, "Antidumping," in E. Kwan Choi and J. Harrigan (Eds.) Handbook of International Economics, (Oxford, UK: Blackwell, 2003). 
Bown, C. and M. Crowley, "Trade Deflection and Trade Depression," Journal of International Economics, 72:1 (2007), 176-201.

Brandt, L., "Land Access, Land Markets, and Their Distributive Implications in Rural Vietnam," University of Toronto mimeograph (2006).

Deaton, A., "Rice prices and income distribution in Thailand: a non-parametric analysis," Economic Journal, 99(Supplement) (1989), 1-37.

Debaere, P. M., "Small Fish - Big Issues: The Effect of Trade Policy on the Global Shrimp Market," CEPR Discussion Paper No. 5254 (2005)

Do, T. and L. Iyer, "Land Tittling and Rural Transition in Vietnam," Economic Development and Cultural Change, 56:3 (2008), 531-579.

Edmonds, E. and N. Pavcnik, "The Effect of Trade Liberalization on Child Labor," Journal of International Economics, 65:2 (2005), 401-419.

Edmonds, E., N. Pavcnik and P. Topalova, "Trade Adjustment and Human Capital Investments: Evidence from Indian Tariff Reform," forthcoming in American Economic Journal: Applied, (2009).

Gallaway, M. P., B. A. Blonigen, and J. E. Flynn, "Welfare Costs of U.S. Antidumping and Countervailing Duty Laws," Journal of International Economics, 49:2 (1999), 211-244.

Jacoby, H, "Shadow Wages and Peasant Family Labor Supply: An Econometric Application to the Peruvian Sierra," Review of Economic Studies, 60:4 (1993), 903-921.

Le, K., "Trade Liberalization Effects in a Predominantly Agricultural Country with Market Imperfections," University of Virginia mimeograph (2008).

Le, K., "Shadow Wages and Shadow Income in Farmers' Labor Supply Functions," American Journal of Agricultural Economics, 91:3 (2009), 685-696.

McCaig, B., "Exporting Out of Poverty: Poverty in Vietnam and U.S. Market Access," University of Toronto mimeograph (2008). 
Nguyen, T., V. Nguyen, and M. Philips, "Implication of Liberation of Fish Trade for Developing Countries, A Case Study of Vietnam," Project PR 26109, (Rome: Food and Agriculture Organization, 2004).

Pagan, A. and A. Ullah (1999). Nonparametric Econometrics (New York: Cambridge University Press).

Prusa, T.J., "The trade effects of U.S. antidumping actions," in R. Feenstra (Ed.) Effects of U.S. Trade Protection and Promotion Policies (Chicago: University of Chicago Press, 1997).

Prusa T.J., "On The Spread and Impact of Antidumping," Canadian Journal of Economics $34: 3$ (2001), 591-611.

Prusa, T.J., "Anti-dumping: A Growing Problem in International Trade," World Economy, $28: 5$ (2005), 683-700.

Robinson, P.M., " $\sqrt{ } N$-Consistent Semi-Parametric Model," Econometrica, 56:4 (1988), 931954.

Seshan, G., "The Impact of Trade Liberalization on Household Welfare in a Developing Country," University of Virginia mimeograph (2006).

Seafood Business Magazine, "Buyer's Guide. Basa Catfish," November (2001).

Staiger, R. and F. Wolak, "Measuring Industry Specific Protection: Antidumping in the United States," Brookings Papers on Economic Activity: Microeconomics, 1 (1994).

Topalova, P., "Trade Liberalization, Poverty, and Inequality: Evidence from Indian Districts," NBER Working Papers 11614 (2005).

Tu, V. B. and P.S. Nguyen, "Mekong Delta Poverty," (Australian Government Project, 2004).

U.S. International Trade Commission, "Industry \& Trade Summary. Fresh or Frozen Fish," USITC Publication 3463 (2001). 
U.S. International Trade Commission, "Certain Frozen Fish Fillets from Vietnam," Investigation No. 731-TA-1012, Publication 3617 (2003).

World Bank, Vietnam: Fisheries and Aquaculture Sector Study, (Washington DC: Rural Development and Natural Resources, East Asia and Pacific Region, 2005).

Zanardi, M., "Anti-dumping: What are the Numbers to Discuss at Doha?," World Economy, 27:3 (2004), 403-433. 
Table 1

Vietnam Aquaculture: Main Species by Region

\begin{tabular}{|c|c|c|c|}
\hline \multirow[t]{2}{*}{ Region } & \multirow{2}{*}{$\begin{array}{l}\text { Freshwater } \\
\text { Aquaculture } \\
\text { (share 2002) }\end{array}$} & \multicolumn{2}{|c|}{ Main Species } \\
\hline & & Freshwater & Brackish \& Marine \\
\hline Mekong & 48.2 & $\begin{array}{l}\text { tra, basa (catfish) } \\
\text { Common carp, tilapia, barb }\end{array}$ & $\begin{array}{l}\text { shrimp } \\
\text { crabs, mollusks }\end{array}$ \\
\hline South East & 33.7 & common carp & $\begin{array}{l}\text { shrimp, mollusks, lobster } \\
\text { grouper, cobia }\end{array}$ \\
\hline South Central & 15.7 & $\begin{array}{l}\text { common carp, grass carp } \\
\text { snakeheads }\end{array}$ & $\begin{array}{l}\text { shrimp } \\
\text { mollusks, pearls, mussels, } \\
\text { scallops } \\
\text { grouper, cobia } \\
\text { lobster }\end{array}$ \\
\hline North East & 59.6 & common carp & $\begin{array}{l}\text { grouper, cobia } \\
\text { shrimp, mollusks } \\
\text { pearls oysters, seaweed }\end{array}$ \\
\hline Red River & 73.9 & Chinese and Indian carp & - \\
\hline North Central & 66.4 & Chinese and Indian carp & $\begin{array}{l}\text { shrimp } \\
\text { seaweed, clams, bivalves } \\
\text { grouper, cobia, red drum }\end{array}$ \\
\hline
\end{tabular}

Note: The table documents the main fish species produced in Vietnam, by region, based on information in World Bank (2005). The share of freshwater aquaculture by region in 2002 is from the Ministry of Fishing, Vietnam (www.fistenet.gov.vn). 
Table 2

Vietnam Aquaculture by Province in the Mekong

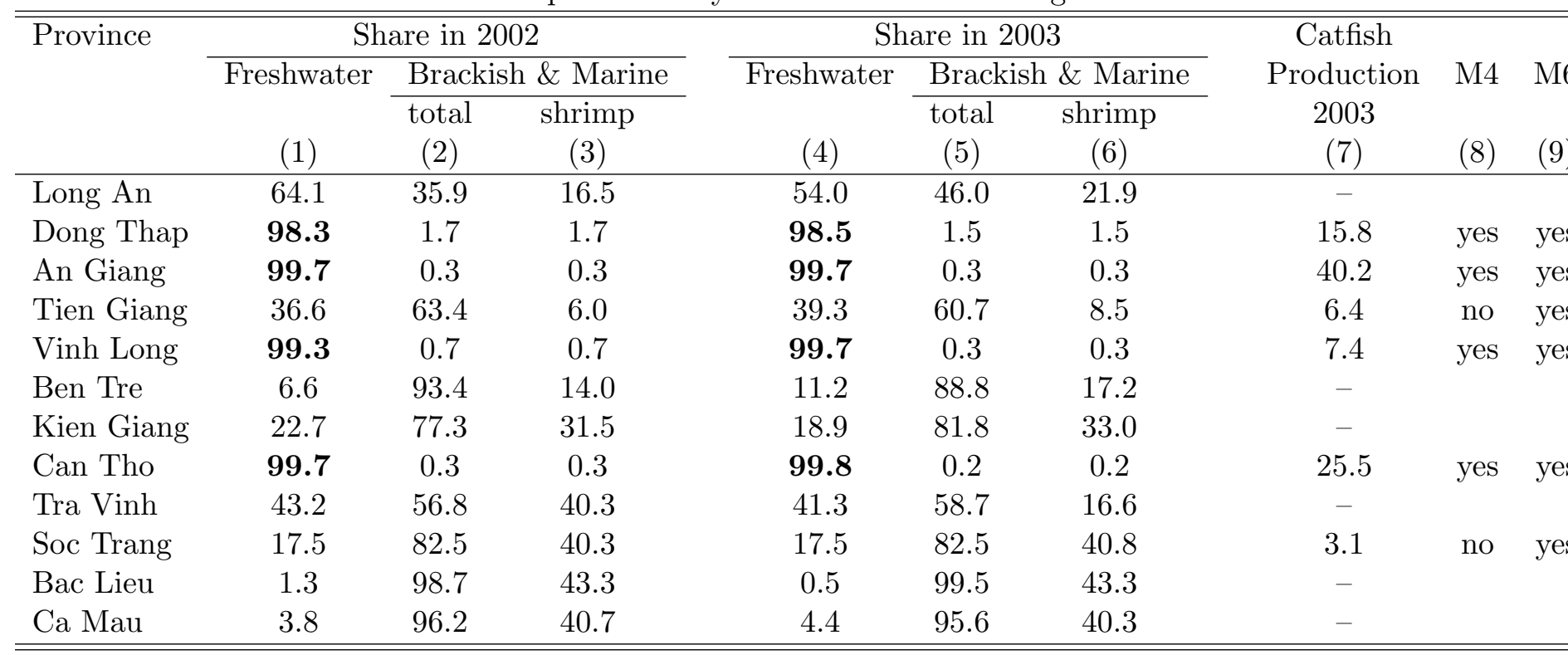

Source: Ministry of Fisheries (www.fistenet.gov.vn) and Seafood from Vietnam Magazine (www. seafoodfromvietnam.com.vn). For 2002 and 2003, the figures show the shares of total aquaculture production from freshwater, brackish \& marine, and shrimp aquaculture. Column 7 reports the fraction of total catfish (tra and basa) production from each province in the Mekong region, calculated from data on total production as well as production by province. Provinces for which the fraction is not reported account for 1.6 percent of total production in the Mekong region. The last two columns indicates the provinces included in areas M4 and M6. 
Table 3

Vietnam Household Living Standards Survey: Panel Sample

Median Annual Household Income

(in thousand 2002 Vietnamese Dong \& PPP U.S. dollars)

\begin{tabular}{|c|c|c|c|c|c|c|c|c|c|}
\hline & \multicolumn{3}{|c|}{ Fishing Households } & \multicolumn{3}{|c|}{ Rural Households } & \multicolumn{3}{|c|}{ All Households } \\
\hline & 2002 & 2004 & Growth & 2002 & 2004 & Growth & 2002 & 2004 & Growth \\
\hline \multicolumn{10}{|l|}{ Mekong 4 (M4) } \\
\hline observations & 561 & 561 & & 864 & 864 & & 1030 & 1030 & \\
\hline per capita income & 3537 & 4224 & $19.4 \%$ & 3375 & 4056 & $20.2 \%$ & 3385 & 3950 & $16.7 \%$ \\
\hline in $\mathrm{PPP} U \$ S$ & 1247 & 1489 & & 1189 & 1431 & & 1193 & 1393 & \\
\hline \multicolumn{10}{|l|}{ Mekong 6 (M6) } \\
\hline observations & 788 & 788 & & 1333 & 1333 & & 1568 & 1568 & \\
\hline per capita income & 3544 & 4281 & $20.8 \%$ & 3359 & 3994 & $18.9 \%$ & 3385 & 3920 & $15.8 \%$ \\
\hline in $\mathrm{PPP} U \$ \mathrm{~S}$ & 1250 & 1509 & & 1184 & 1409 & & 1193 & 1383 & \\
\hline \multicolumn{10}{|c|}{ South Vietnam (non-Mekong) } \\
\hline observations & 384 & 384 & & 3195 & 3195 & & 4424 & 4424 & \\
\hline per capita income & 3140 & 3673 & $17.0 \%$ & 3037 & 3728 & $22.8 \%$ & 3230 & 3878 & $20.1 \%$ \\
\hline in PPP U\$S & 1107 & 1295 & & 1070 & 1315 & & 1138 & 1368 & \\
\hline
\end{tabular}

Note: Authors' calculations based on the panel sample of the Vietnam Household Living Standard Surveys, 2002 and 2004. Mekong 4 (M4) and Mekong 6 (M6) refer to two sets of Mekong provinces that specialize in catfish production: M4 includes An Giang, Can Tho, Dong Thap and Vinh Long, and M6 adds Soc Trang and Tien Giang. 
Table 4

Vietnam Household Living Standards Survey

Sources of Income

Panel Sample

\begin{tabular}{lccccc}
\hline \hline & \multicolumn{2}{c}{ Mekong $4(\mathrm{M} 4)$} & & \multicolumn{2}{c}{ Mekong 6 (M6) } \\
\cline { 2 - 3 } \cline { 5 - 6 } & 2002 & 2004 & & 2002 & 2004 \\
\hline Fish Farming & 11.2 & 6.8 & & 9.6 & 6.5 \\
Other Aquaculture & 1.0 & 1.0 & & 1.2 & 1.3 \\
Wages & 26.7 & 28.1 & & 25.7 & 27.4 \\
Agriculture & 42.5 & 43.2 & & 44.3 & 43.4 \\
$\quad$ sales & 33.5 & 33.2 & & 35.6 & 34.5 \\
own & 9.0 & 10.1 & & 8.7 & 8.9 \\
Miscellaneous Farm Activities & 10.8 & 11.6 & & 11.9 & 12.7 \\
$\quad$ Livestock & 9.5 & 10.4 & & 10.6 & 11.6 \\
Silviculture & 0.6 & 0.6 & & 0.6 & 0.5 \\
Farm Services & 0.7 & 0.6 & & 0.7 & 0.6 \\
Other & 7.8 & 9.3 & & 7.4 & 8.8 \\
\hline \hline
\end{tabular}

Note: Own calculations based on the panel sample of the Vietnam Household Living Standard Surveys, 2002 and 2004. Mekong 4 (M4) and Mekong 6 (M6) refer to two sets of Mekong provinces that specialize in catfish production: M4 includes An Giang, Can Tho, Dong Thap and Vinh Long, and M6 adds Soc Trang and Tien Giang. 
Table 5

Average Impact of Anti-Dumping on Income

Mekong Provinces

All Farms

\begin{tabular}{|c|c|c|c|c|c|c|}
\hline & \multicolumn{2}{|c|}{ Total Income } & \multicolumn{2}{|c|}{ Per Capita Income } & \multicolumn{2}{|c|}{ Net Income } \\
\hline & $\begin{array}{l}\text { M4 } \\
(1) \\
\end{array}$ & $\begin{array}{l}\text { M6 } \\
(2) \\
\end{array}$ & $\begin{array}{l}\text { M4 } \\
(3) \\
\end{array}$ & $\begin{array}{l}\text { M6 } \\
(4)\end{array}$ & $\begin{array}{l}\text { M4 } \\
(5)\end{array}$ & $\begin{array}{l}\text { M6 } \\
(6)\end{array}$ \\
\hline \multicolumn{7}{|c|}{ A) Quadratic Model } \\
\hline $\begin{array}{l}\text { Low Exposure } \\
\left(s^{c}=0.055\right)\end{array}$ & $\begin{array}{c}-0.087^{* * *} \\
(0.033)\end{array}$ & $\begin{array}{c}-0.071^{* * *} \\
(0.028)\end{array}$ & $\begin{array}{c}-0.089^{* * *} \\
(0.033)\end{array}$ & $\begin{array}{c}-0.073^{* * *} \\
(0.028)\end{array}$ & $\begin{array}{c}-0.105^{* * *} \\
(0.032)\end{array}$ & $\begin{array}{c}-0.089^{* * *} \\
(0.028)\end{array}$ \\
\hline $\begin{array}{l}\text { Mean Exposure } \\
\left(s^{c}=0.112\right)\end{array}$ & $\begin{array}{c}-0.158^{* * *} \\
(0.057)\end{array}$ & $\begin{array}{c}-0.129^{* * *} \\
(0.050)\end{array}$ & $\begin{array}{c}-0.162^{* * *} \\
(0.056)\end{array}$ & $\begin{array}{c}-0.132^{* * *} \\
(0.050)\end{array}$ & $\begin{array}{c}-0.188^{* * *} \\
(0.054)\end{array}$ & $\begin{array}{c}-0.160^{* * *} \\
(0.048)\end{array}$ \\
\hline $\begin{array}{l}\text { High Exposure } \\
\left(s^{c}=0.200\right)\end{array}$ & $\begin{array}{c}-0.236^{* * *} \\
(0.080)\end{array}$ & $\begin{array}{c}-0.192^{* * *} \\
(0.072)\end{array}$ & $\begin{array}{c}-0.241^{* * *} \\
(0.079)\end{array}$ & $\begin{array}{c}-0.196^{* * *} \\
(0.072)\end{array}$ & $\begin{array}{c}-0.276^{* * *} \\
(0.075)\end{array}$ & $\begin{array}{c}-0.236^{* * *} \\
(0.068)\end{array}$ \\
\hline Observations & 1728 & 2656 & 1728 & 2656 & 1726 & 2648 \\
\hline $\mathrm{R}^{2}$ (within) & 0.156 & 0.149 & 0.154 & 0.151 & 0.144 & 0.138 \\
\hline \multicolumn{7}{|c|}{ B) Partially Linear Model } \\
\hline $\begin{array}{l}\text { Low Exposure } \\
\left(s^{c}=0.055\right)\end{array}$ & $\begin{array}{c}-0.094^{* * *} \\
(0.022)\end{array}$ & $\begin{array}{c}-0.071^{* * *} \\
(0.019)\end{array}$ & $\begin{array}{c}-0.099^{* * *} \\
(0.022)\end{array}$ & $\begin{array}{c}-0.073^{* * *} \\
(0.020)\end{array}$ & $\begin{array}{c}-0.120^{* * *} \\
(0.023)\end{array}$ & $\begin{array}{c}-0.101^{* * *} \\
(0.022)\end{array}$ \\
\hline $\begin{array}{l}\text { Mean Exposure } \\
\left(s^{c}=0.112\right)\end{array}$ & $\begin{array}{c}-0.169^{* * *} \\
(0.033)\end{array}$ & $\begin{array}{c}-0.135^{* * *} \\
(0.031)\end{array}$ & $\begin{array}{c}-0.177^{* * *} \\
(0.034)\end{array}$ & $\begin{array}{c}-0.138^{* * *} \\
(0.032)\end{array}$ & $\begin{array}{c}-0.214^{* * *} \\
(0.035)\end{array}$ & $\begin{array}{c}-0.188^{* * *} \\
(0.035)\end{array}$ \\
\hline $\begin{array}{l}\text { High Exposure } \\
\left(s^{c}=0.200\right)\end{array}$ & $\begin{array}{c}-0.243^{* * *} \\
(0.055)\end{array}$ & $\begin{array}{c}-0.205^{* * *} \\
(0.057)\end{array}$ & $\begin{array}{c}-0.247^{* * *} \\
(0.056)\end{array}$ & $\begin{array}{c}-0.205^{* * *} \\
(0.059)\end{array}$ & $\begin{array}{c}-0.302^{* * *} \\
(0.057)\end{array}$ & $\begin{array}{c}-0.275^{* * *} \\
(0.064)\end{array}$ \\
\hline Observations & 1576 & 2656 & 1576 & 2656 & 1576 & 2648 \\
\hline
\end{tabular}

Note: Estimates of model (1) in the text for total household income (columns 1 and 2), per capita household income (columns 3 and 4), and net income (columns 5 and 6). All dependent variables are in logarithm. The impacts are evaluated at three different levels of exposure: low exposure (the median share), average exposure (the mean share), and high exposure (the median share for farmers with shares above the mean). The regressions are run on the sample of all farmers (See Supplemental Web Appendix for results for a subset of catfish farmers only). Panel A) reports results from a quadratic model in initial shares, and Panel B) reports results from a partially linear model (Robinson, 1988). Mekong 4 (M4) and Mekong 6 (M6) refer to two sets of Mekong provinces that specialize in catfish production: M4 includes An Giang, Can Tho, Dong Thap and Vinh Long, and M6 adds Soc Trang and Tien Giang.

Robust standard errors within parenthesis: $*, * *, * * *$, significant at 10\%, 5\%, and $1 \%$ level, respectively. 
Table 6

Average Impact of Anti-Dumping on Income

Mekong \& South Provinces

All Farms

\begin{tabular}{|c|c|c|c|c|c|c|}
\hline & \multicolumn{2}{|c|}{ Total Income } & \multicolumn{2}{|c|}{ Per Capita Income } & \multicolumn{2}{|c|}{ Net Income } \\
\hline & $\begin{array}{l}\text { M4 } \\
(1) \\
\end{array}$ & $\begin{array}{l}\text { M6 } \\
(2) \\
\end{array}$ & $\begin{array}{c}\text { M4 } \\
(3)\end{array}$ & $\begin{array}{c}\text { M6 } \\
(4)\end{array}$ & $\begin{array}{l}\mathrm{M} 4 \\
(5)\end{array}$ & $\begin{array}{c}\text { M6 } \\
(6) \\
\end{array}$ \\
\hline \multicolumn{7}{|l|}{ A) Mekong } \\
\hline Low Exposure & $\begin{array}{c}-0.128^{* * *} \\
(0.037)\end{array}$ & $\begin{array}{c}-0.122^{* * *} \\
(0.035)\end{array}$ & $\begin{array}{c}-0.124^{* * *} \\
(0.037)\end{array}$ & $\begin{array}{c}-0.118^{* * *} \\
(0.034)\end{array}$ & $\begin{array}{c}-0.167^{* * *} \\
(0.034)\end{array}$ & $\begin{array}{c}-0.160^{* * *} \\
(0.031)\end{array}$ \\
\hline Mean Exposure & $\begin{array}{c}-0.229^{* * *} \\
(0.062)\end{array}$ & $\begin{array}{c}-0.218^{* * *} \\
(0.058)\end{array}$ & $\begin{array}{c}-0.223^{* * *} \\
(0.062)\end{array}$ & $\begin{array}{c}-0.211^{* * *} \\
\quad(0.058)\end{array}$ & $\begin{array}{c}-0.293^{* * *} \\
(0.054)\end{array}$ & $\begin{array}{c}-0.281^{* * *} \\
(0.051)\end{array}$ \\
\hline High Exposure & $\begin{array}{c}-0.338^{* * *} \\
(0.083) \\
\end{array}$ & $\begin{array}{c}-0.321^{* * *} \\
(0.079) \\
\end{array}$ & $\begin{array}{c}-0.329^{* * *} \\
(0.083) \\
\end{array}$ & $\begin{array}{c}-0.311^{* * *} \\
(0.079) \\
\end{array}$ & $\begin{array}{c}-0.422^{* * *} \\
(0.069) \\
\end{array}$ & $\begin{array}{c}-0.408^{* * *} \\
(0.065) \\
\end{array}$ \\
\hline $\begin{array}{l}\text { B) South } \\
\text { Low Exposure }\end{array}$ & $\begin{array}{c}0.043 \\
(0.028)\end{array}$ & $\begin{array}{c}0.043 \\
(0.028)\end{array}$ & $\begin{array}{c}0.037 \\
(0.027)\end{array}$ & $\begin{array}{c}0.037 \\
(0.027)\end{array}$ & $\begin{array}{c}0.070^{* * *} \\
(0.025)\end{array}$ & $\begin{array}{c}0.069^{* * *} \\
(0.026)\end{array}$ \\
\hline Mean Exposure & $\begin{array}{c}0.085 \\
(0.055)\end{array}$ & $\begin{array}{c}0.084 \\
(0.055)\end{array}$ & $\begin{array}{c}0.074 \\
(0.053)\end{array}$ & $\begin{array}{c}0.072 \\
(0.053)\end{array}$ & $\begin{array}{c}0.140^{* * *} \\
(0.051)\end{array}$ & $\begin{array}{c}0.138^{* * *} \\
(0.051)\end{array}$ \\
\hline High Exposure & $\begin{array}{c}0.143 \\
(0.091)\end{array}$ & $\begin{array}{c}0.140 \\
(0.092)\end{array}$ & $\begin{array}{c}0.125 \\
(0.088)\end{array}$ & $\begin{array}{c}0.122 \\
(0.088)\end{array}$ & $\begin{array}{c}0.239^{* * *} \\
(0.087)\end{array}$ & $\begin{array}{c}0.235^{* * *} \\
(0.087)\end{array}$ \\
\hline Observations & 8108 & 9041 & 8108 & 9041 & 8096 & 9026 \\
\hline $\mathrm{R}^{2}$ (within) & 0.224 & 0.215 & 0.207 & 0.200 & 0.216 & 0.207 \\
\hline
\end{tabular}

Note: Estimates of model (2) in the text for total household income (columns 1 and 2), per capita household income (columns 3 and 4), and net income (columns 5 and 6). All dependent variables are in logarithm. Based on a quadratic model in initial shares evaluated at three different levels of exposure: low exposure (the median share), average exposure (the mean share), and high exposure (the median share for farmers with shares above the mean). The regressions are run on the sample of all farmers (See Supplemental Web Appendix for results for a subset of catfish farmers only). Panel A) reports results for Mekong farmers and Panel B), for South farmers. Mekong 4 (M4) and Mekong 6 (M6) refer to two sets of Mekong provinces that specialize in catfish production: M4 includes An Giang, Can Tho, Dong Thap and Vinh Long, and M6 adds Soc Trang and Tien Giang. South refers to non-Mekong farms in Southern Vietnam (see text).

Robust standard errors within parenthesis: $*, * *$ and $* * *$ indicate significance at $10 \%, 5 \%$, and $1 \%$ level, respectively. 


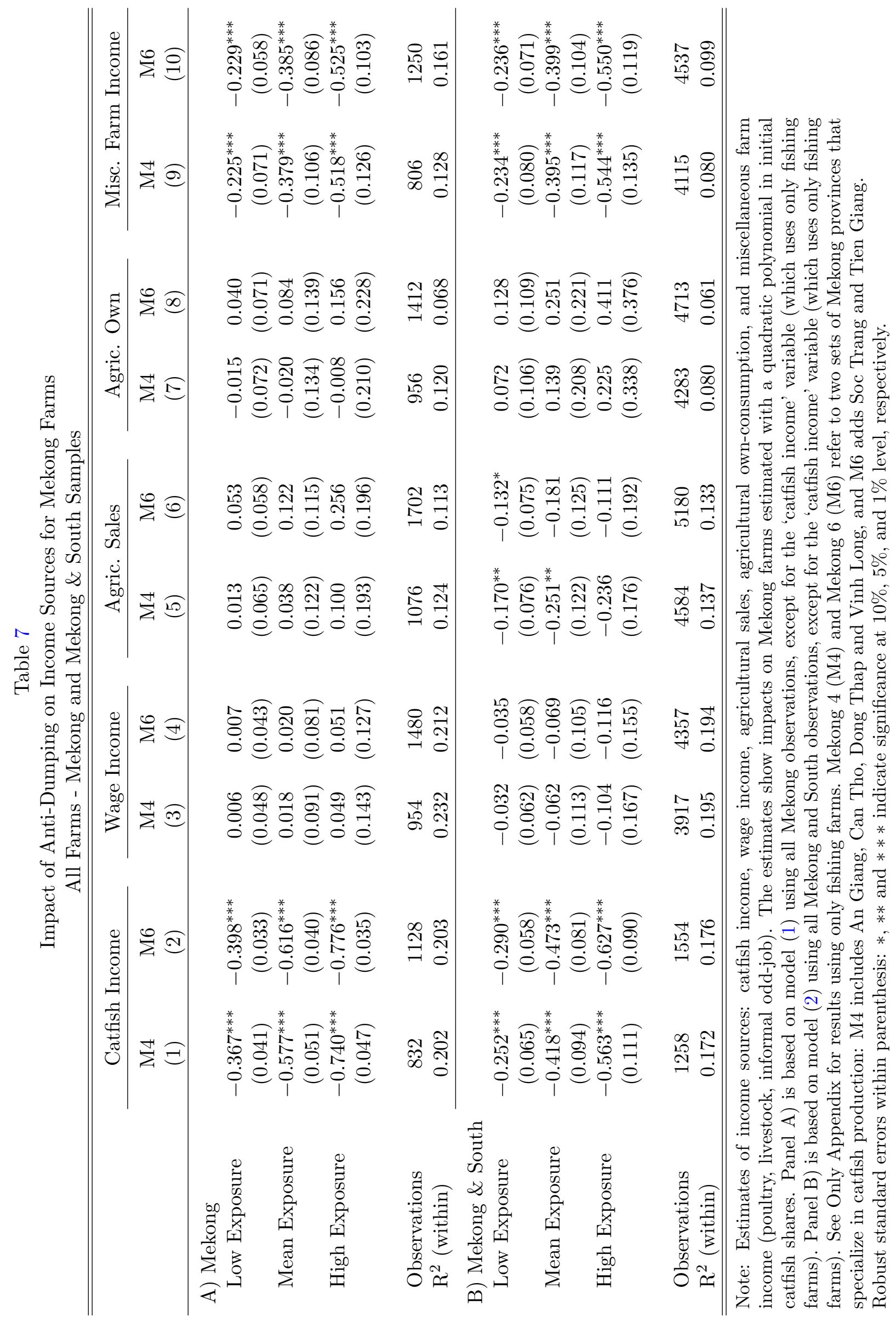




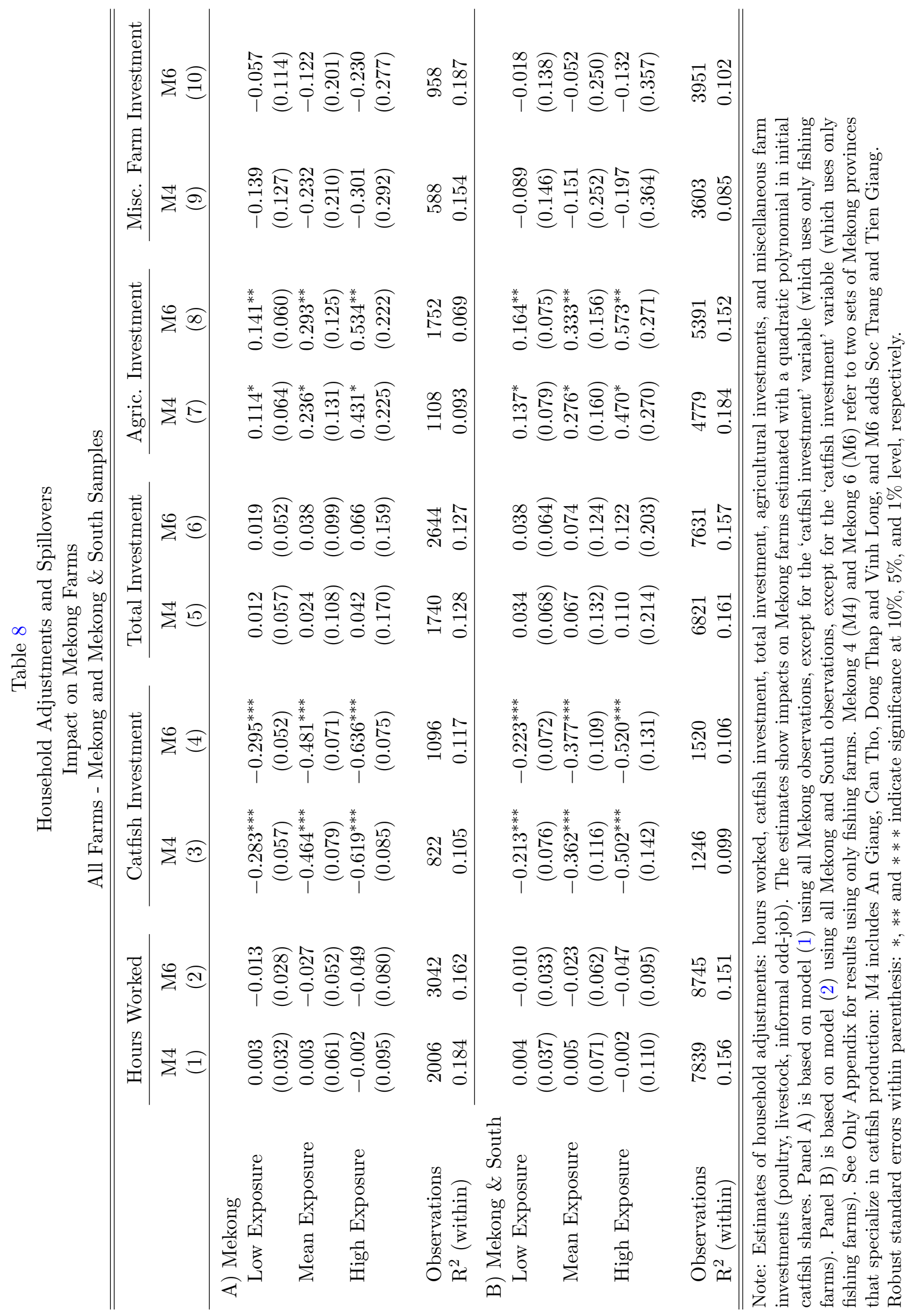




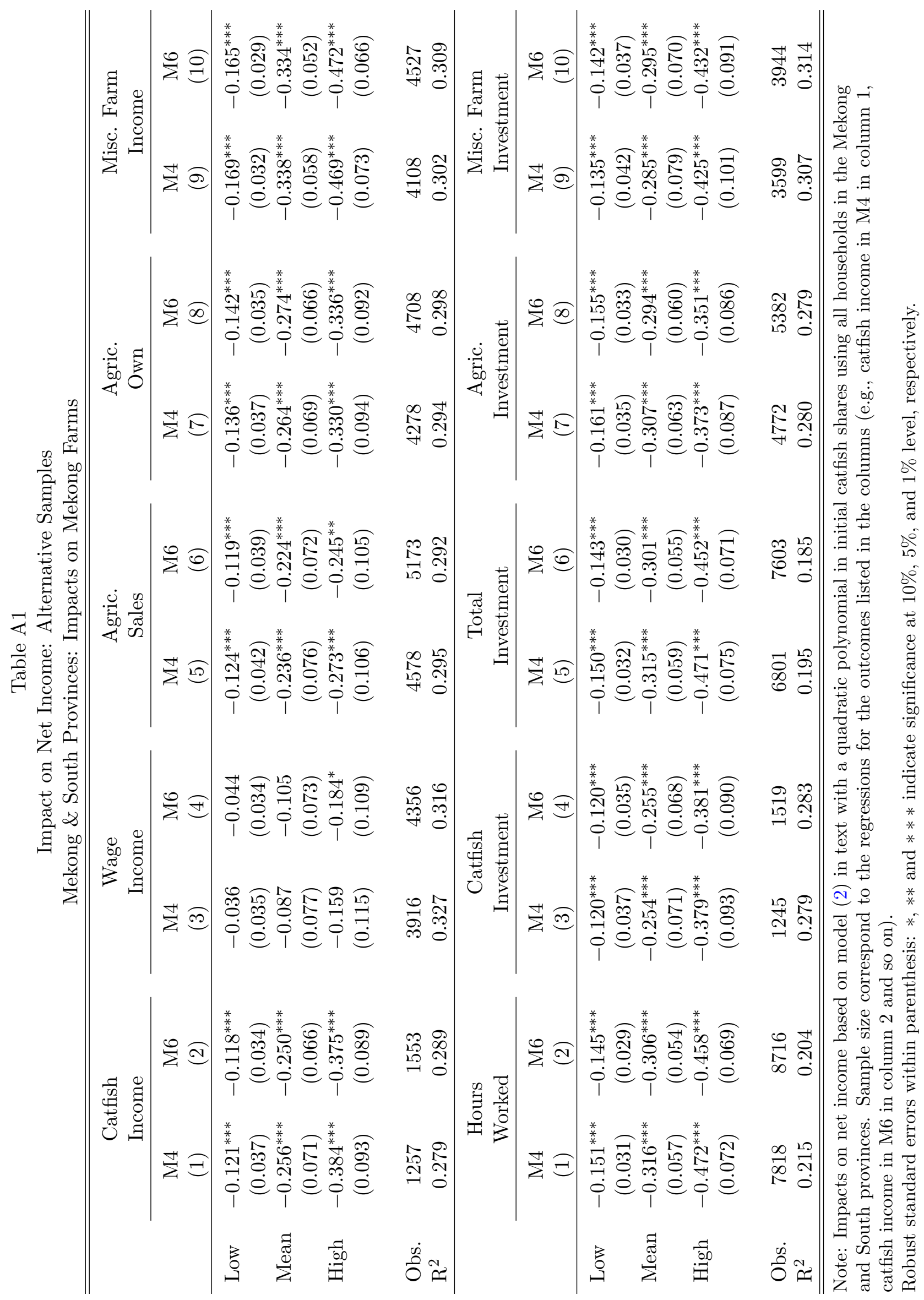

